\title{
Rubiaceae Juss. da restinga da APA de Algodoal/Maiandeua, Maracanã, Pará, Brasil Rubiaceae Juss. of the restinga from APA of Algodoal/Maiandeua, Maracanã, Pará, Brazil
}

\author{
Luciano Ferreira Margalho' \\ Antonio Elielson Sousa da Rocha" \\ Ricardo de Souza Seccolli
}

Resumo: As Rubiaceae estão representadas na Área de Proteção Ambiental (APA) de Algodoal/Maiandeua por 17 espécies, distribuídas em 15 gêneros. As tribos com o maior número de espécies foram Gardenieae, com quatro, e Spermacoceae, com três. Guettarda e Psychotria apresentaram duas espécies cada um, os demais gêneros apenas uma. Três espécies de Rubiaceae da restinga foram sinonimizadas, Alibertia myrciifolia Spruce ex K. Schum. (= Cordiera myrciifolia (Spruce ex K. Schum.) C. Persson \& Delprete), Psychotria barbiflora DC. (= P. hoffmannseggiana (Willd. ex Roem. \& Schult.) Müll. Arg.) e Tocoyena sprucei Standl. (= T. brasiliensis Mart.). As espécies de Rubiaceae encontram-se mais concentradas na formação de mata de Myrtaceae, diminuindo, em número de espécies, em direção à praia. Guettarda spruceana Müll. Arg., Oldenlandia tenuis K. Schum., Posoqueria latifolia (Rudge) Roem. \& Schult. e Retiniphyllum schomburgkii (Benth.) Müll. Arg. são novos registros para a APA de Algodoal/Maiandeua.

Palavras-chave: Taxonomia. Florística. Vegetação litorânea. Estado do Pará.

Abstract: Rubiaceae is represented in the Ambiental Preservation Area (APA) of Algodoal/Maiandeua by 17 species, distributed over 15 genera. The tribes with most species were Gardenieae, with four species and Spermacoceae, with three. Guettarda and Psychotria contain two species each, and the other genera one. Three species of Rubiaceae from the restinga were sinonimized, Alibertia myrciifolia Spruce ex K. Schum. (= Cordiera myrciifolia (Spruce ex K. Schum.) C. Persson \& Delprete), Psychotria barbiflora DC. (= P. hoffmannseggiana (Willd. ex Roem. \& Schult.) Müll. Arg.) e Tocoyena sprucei Standl. (= T. brasiliensis Mart.). The species of Rubiaceae are more concentrated in the Myrtaceae forest, diminishing, in number of species, in direction to the beach. Guettarda spruceana Müll. Arg., Oldenlandia tenuis K. Schum., Posoqueria latifolia (Rudge) Roem. \& Schult. and Retiniphyllum schomburgkii (Benth.) Müll. Arg. are new records for the APA of Algodoal/Maiandeua.

Keywords: Taxonomy. Floristic. Littoral vegetation. Pará State.

I Museu Paraense Emílio Goeldi. Coordenação de Botânica. Belém, Pará, Brasil (lucianomargalho@hotmail.com).

" Museu Paraense Emílio Goeldi. Coordenação de Botânica. Belém, Pará, Brasil (asrocha@museu-goeldi.br).

III Museu Paraense Emílio Goeldi. Coordenação de Botânica. Belém, Pará, Brasil (rsecco@museu-goeldi.br).

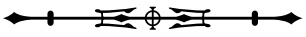




\section{INTRODUÇÃO}

Rubiaceae Juss. é a quarta maior família das fanerógamas (Delprete, 1999). Taylor et al. (2004) registraram no mundo 650 gêneros e 13.000 espécies (Delprete \& Persson, 2004). No Brasil, de acordo com a "Flora Brasiliensis", Mueller Argoviensis (1881)e Schumann $(1888,1889)$ reportaram 99 gênerose 1.002 espécies. Atualmente, no Brasil, ocorrem cerca de 130 gêneros e 1.500 espécies, correspondendo a uma das principais familias de nossa flora e destacando-se como um importante elemento em quase todas as formações naturais (Souza \& Lorenzi, 2005). No primeiro registro sobre a distribuição geográfica das Rubiáceas para a Amazônia (Náiade), segundo Schumann (1889), foram contabilizadas 258 espécies, sendo 174 endêmicas (Chiquieriet al., 2004). O levantamento atual das espécies de Rubiáceas na Amazônia foi pontual em um trecho de 89 hectares de floresta de terra firme, localizado a $90 \mathrm{~km}$ ao norte de Manaus, onde foram encontradas 62 espécies (Boom \& Campos, 1991). Para a Reserva Ducke (Manaus, Amazonas), Campos et al. (1999) citaram 35 gêneros e 90 espécies. Para a Área de Proteção Ambiental (APA) de Algodoal/Maiandeua, Amaral et al. (2008) citaram 13 gêneros e 18 espécies.

Espécies de Rubiaceae apresentam distribuição cosmopolita, sendo mais abundantes nas regiões tropicais, em ambos os hemisférios (Taylor et al., 2004).

Rubiaceae é conhecida por ser uma família de difícil classificação em nível de subfamília (Bremer et al., 1995). Schumann (1891) dividiu as Rubiaceae em duas subfamílias: Cinchonoideae e Coffeoideae, baseado em um único caráter, o número de óvulos por lóculo (Bremer et al., 1995). Engler (1954) colocou Rubiaceae na classe Dicotyledoneae, subclasse Metachlamydeae, série Rubiales, baseando-se, principalmente, no número de cotilédones na semente e na soldadura dos verticilos florais. Verdcourt (1958) dividiu Rubiaceae em três subfamílias: Rubioideae, Cinchonoideae e Guettardoideae, baseando-se em várias características, como hábito, forma de estípulas, tipo de indumento, presença de ráfides nas folhas, prefloração das corolas, entre outras. Cronquist (1981) posicionou Rubiaceae na classe Magnoliatae, subclasse Asteridae, ordem Rubiales. De acordo com APG II (2003), Rubiaceae pertence ao grupo das Asteridae, subgrupo das Euasteridae I, ordem Gentianales. Robbrecht $(1988,1993)$ reconheceu quatro subfamílias, Cinchonoideae, Ixoroideae, Rubioideae e Antirheoideae, e 44 tribos. Estudos filogenéticos mais recentes, baseados em dados moleculares, como os de Bremer et al. (1995, 1999), reconheceram apenas três: Cinchonoideae, Ixoroideae e Rubioideae. Atualmente, Robbrecht \& Manen (2006) reconhecem apenas duas subfamilias, Cinchonoideae e Rubioideae, e quatro supertribos.

Barroso et al. (1991) destacaram como principais características de Rubiaceae as estípulas interpeciolares bem desenvolvidas, tricomas glandulares especializados (coléteres), estrutura da parede do pólen, presença de alcalóides complexos da família triptofano, geralmente ovário ínfero (súpero em Pagamea Aubl.) e ausência de floema interno.

Dando prosseguimento aos estudos taxonômicos na restinga daAPA de Algodoal/Maiandeua, estado do Pará, propôsse o estudo das Rubiáceas existentes na área, por ser um grupo de plantas de interesse econômico e pouco estudado na região.

\section{MATERIAL E MÉTODOS}

\section{ÁREA DE ESTUDO}

A APA de Algodoal/Maiandeua localiza-se no município de Maracanã, nordeste do estado do Pará, Brasil. Essa APA é uma itha oceânica, conhecida como ilha de Algodoal, situada a 200 km de Belém, entre as coordenadas geográficas $00^{\circ} 35^{\prime} 03^{\prime \prime}$ a $00^{\circ} 38^{\prime} 29^{\prime \prime}$ de latitude sul e $47^{\circ} 31^{\prime} 54^{\prime \prime}$ a $47^{\circ} 34^{\prime}$ '57" de longitude oeste.

A APA é constituída de cinco tipos de vegetação: o mangue na porção sul, centro e norte da ilha; apicuns nas zonas hipersalinas; mata permanente inundada em pequenas manchas; vegetação secundária no centro-sul da ilha; e vegetação de restinga que ocupa uma grande faixa da planície arenosa na porção norte, nordeste e oeste da ilha. Estas se apresentam, segundo Bastos et al. (1995, 2002), como um complexo constituído por formações variadas: halófita (na praia), psamófila reptante (sobre os primeiros cordões dunares), brejo herbáceo (em reverso de cordão dunar), campo entre dunas

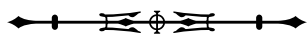


(na região entre as dunas), dunas (no campo entre dunas), formação arbustiva aberta (formação aberta com moita, em área plana entre dunas interiores) e mata de restinga ou mata de Myrtaceae (próximo à praia, sobre ressalto topográfico ou bastante afastada desta, nas partes mais internas).

\section{METODOLOGIA}

O estudo foi baseado em material herborizado proveniente da APA de Algodoal/Maiandeua, depositado nos herbários do Museu Paraense Emílio Goeldi (MG) e Embrapa Amazônia Oriental (IAN). Adicionalmente, foram realizadas novas coletas, seguindo as técnicas propostas por Fidalgo \& Bononi (1989), as quais foram realizadas nos meses de outubro de 2006 e fevereiro de 2007. A identificação das espécies foi baseada em amostras de herbário determinadas por especialistas, diagnoses e descrições existentes na literatura especializada (Schumann, 1888, 1889; Steyermark, 1965,
1972; Dwyer, 1980; Mendoza et al., 2004 e Taylor et al., 2004) e, quando possível, auxiliada por comparação com a foto do tipo e orientações de especialistas.

A nomenclatura adotada para indicar a forma e o indumento das estruturas morfológicas foi baseada nos trabalhos de Schultz (1963), Lawrence (1973) e Rizzini (1977).

O sistema de classificação adotado para a ordem segue APG II (2003)e para as subfamílias, Robbrecht \& Manen (2006).

Os nomes dos autores de plantas seguem Brummitt \& Powell (1992) e os nomes das espécies foram consultados, além dos trabalhos especializados, junto ao Tropicos (2009).

\section{RESULTADOS}

Na APA de Algodoal/Maiandeua, Rubiaceae está representada pelas subfamilias Rubioideae e Cinchonoideae (Robbrecht \& Manen, 2006), com 17 espécies, distribuídas em 15 gêneros (Tabela 1).

Tabela 1. Classificação das espécies de Rubiaceae da APA de Algodoal/Maiandeua sensu Robbrecht \& Manen (2006).

\begin{tabular}{|c|c|c|c|c|c|}
\hline Subfamília & Clado & Supertribo & Tribo & Subtribo & Espécie \\
\hline \multirow{9}{*}{ Cinchonoideae } & & \multirow{6}{*}{ Ixoridinae } & \multirow{4}{*}{ Gardenieae } & & Alibertia edulis (Rich.) A. Rich. ex DC. \\
\hline & & & & & $\begin{array}{l}\text { Cordiera myrciifolia (Spruce ex K. Schum.) C. } \\
\text { Persson \& Delprete }\end{array}$ \\
\hline & & & & & Duroia genipoides Hook. f. ex K. Schum. \\
\hline & & & & & Tocoyena brasiliensis Mart. \\
\hline & & & Henriquezieae & Posoqueriinae & Posoqueria latifolia (Rudge) Roem. \& Schult. \\
\hline & & & Retiniphylleae & & Retiniphyllum schomburgkii (Benth.) Müll. Arg. \\
\hline & & \multirow{3}{*}{ Cinchonidinae } & Chiococceae & & Chiococca nitida Benth. \\
\hline & & & \multirow{2}{*}{ Guettardeae } & & Guettarda angelica Mart. ex Müll. Arg. \\
\hline & & & & & Guettarda spruceana Müll. Arg. \\
\hline \multirow{8}{*}{ Rubioideae } & \multirow{2}{*}{$\begin{array}{l}\text { Rubioideae } \\
\text { Basais }\end{array}$} & & Coussareeae & & Faramea nitida Benth. \\
\hline & & & Perameae & & Perama hirsuta Aubl. \\
\hline & & \multirow{3}{*}{ Rubiidinae } & \multirow{3}{*}{ Spaermacoceae } & & Borreria verticillata (L.) G. Mey. \\
\hline & & & & & $\begin{array}{l}\text { Mitracarpus frigidus (Willd. ex Roem. \& Schult.) } \\
\text { K. Schum. var. discolor (Miq.) K. Schum. }\end{array}$ \\
\hline & & & & & Oldenlandia tenuis K. Schum. \\
\hline & & \multirow{3}{*}{ Psychotriidinae } & Gaertnereae & & Pagamea guianensis Aubl. \\
\hline & & & \multirow[t]{2}{*}{ Psychotrieae } & & $\begin{array}{l}\text { Psychotria hoffmannseggiana } \\
\text { (Willd. ex Roem. \& Schult.) Müll. Arg. }\end{array}$ \\
\hline & & & & & Psychotria mapourioides DC. \\
\hline
\end{tabular}

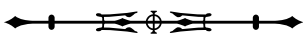




\section{DISTRIBUIÇÃO DAS ESPÉCIES DE RUBIACEAE NA APA DE ALGODOAL/MAIANDEUA}

A formação mata de Myrtaceae concentrou o maior número de espécies na APA (11), diminuindo em direção à praia (Tabela 2), o que demonstra que a família é mais adaptada a lugares mais úmidos e menos expostos aos raios solares. Além disso, essa distribuição também revela que as espécies de Rubiaceae são pouco tolerantes à salinidade. Nesse contexto, verificou-se que a vegetação psamófila reptante, a qual está localizada mais próxima ao mar, foi a única formação vegetal que não apresentou nenhum indivíduo neste estudo.

Oldenlandia tenuis e Posoqueria latifolia são novos registros para a restinga da Amazônia, com base na lista apresentada por Amaral et al. (2008).
Baseando-se no levantamento bibliográfico (Tabela 3), conclui-se que, das 17 espécies aqui tratadas, apenas sete foram registradas em outras restingas brasileiras, sendo as do estado do Rio de Janeiro aquelas que apresentam o maior número de espécies em comum com a APA de Algodoal/ Maiandeua. As áreas de restingas daquele estado, juntas, apresentam a maior riqueza de espécies de Rubiaceae no Brasil, seguidas da APA de Algodoal/ Maiandeua. As demais áreas em ordem decrescente de riqueza de espécies são: Espírito Santo (sete) e Bahia (cinco).

Ainda de acordo com este levantamento, Oldenlandia tenuis é registrada pela primeira vez em vegetação de restinga no Brasil.

Tabela 2. Formações vegetais onde ocorrem as espécies encontradas na APA de Algodoal/Maiandeua.

\begin{tabular}{|c|c|c|c|c|}
\hline Espécies & Brejo herbáceo & Campo entre dunas & $\begin{array}{c}\text { Formação arbustiva } \\
\text { aberta }\end{array}$ & Mata de Myrtaceae \\
\hline Alibertia edulis & & & $x$ & $x$ \\
\hline Borreria verticillata & $x$ & $x$ & & \\
\hline Chiococca nitida & & & & $x$ \\
\hline Cordiera myrciifolia & & & & $x$ \\
\hline Duroia genipoides & & & & $x$ \\
\hline Faramea nitida & & & & $x$ \\
\hline Guettarda angelica & & & & $x$ \\
\hline Guettarda spruceana & & & & $x$ \\
\hline Mitracarpus frigidus var. discolor & & $x$ & & \\
\hline Oldenlandia tenuis & & $x$ & & \\
\hline Pagamea guianensis & & & $x$ & $x$ \\
\hline Perama hirsuta & & & $x$ & \\
\hline Posoqueria latifolia & & $x$ & & \\
\hline Psychotria hoffmannseggiana & & & $x$ & $x$ \\
\hline Psychotria mapourioides & & & $x$ & $x$ \\
\hline Retiniphyllum schomburgkii & & $x$ & & \\
\hline Tocoyena brasiliensis & & & $x$ & $x$ \\
\hline
\end{tabular}

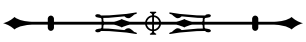


Tabela 3. Ocorrência de algumas espécies de Rubiaceae nas restingas brasileiras.

\begin{tabular}{|c|c|c|c|c|c|c|c|}
\hline $\begin{array}{c}\text { APA de Aldogoal/ } \\
\text { Maiandeua } \\
\text { (este estudo) }\end{array}$ & $\begin{array}{c}\text { APA de Algodoal/ } \\
\text { Maiandeua (Tese } \\
\text { de Doutorado de } \\
\text { M. N. C. BASTOS, } \\
\text { de 1996, intitulada } \\
\text { "Caracterização das } \\
\text { formações vegetais } \\
\text { da restinga da } \\
\text { Princesa, ilha de } \\
\text { Algodoal-PA") }\end{array}$ & $\begin{array}{c}\text { Praia da Boa } \\
\text { Viagem, Recife, } \\
\text { Pernambuco } \\
\text { (Leite \& Andrade, } \\
\text { 2004) }\end{array}$ & $\begin{array}{l}\text { Bahia (Pinto } \\
\text { et al., 1984) }\end{array}$ & $\begin{array}{c}\text { Abaeté, } \\
\text { Salvador, Bahia } \\
\text { Viana et al., } \\
\text { 2006) }\end{array}$ & $\begin{array}{c}\text { Espírito Santo } \\
\text { (Assis et al., } \\
\text { 2004) }\end{array}$ & $\begin{array}{l}\text { Rio de Janeiro } \\
\text { (Tese de } \\
\text { Doutorado de } \\
\text { D. S. D. Araújo, } \\
\text { de 2000, intitulada } \\
\text { "Análise florística e } \\
\text { fitogeográfica } \\
\text { das restingas do } \\
\text { Estado do } \\
\text { Rio de Janeiro") }\end{array}$ & $\begin{array}{c}\text { São João da } \\
\text { Barra, Rio } \\
\text { de Janeiro } \\
\text { (Assumpção } \\
\text { \& } \\
\text { Nascimento, } \\
\text { 2000) }\end{array}$ \\
\hline Borreria verticillata & Presente & Presente & & Presente & & & Presente \\
\hline Guettarda angelica & Presente & & Presente & & & & \\
\hline $\begin{array}{l}\text { Mitracarpus frigidus } \\
\text { var. discolor }\end{array}$ & & & & Presente & & Presente & \\
\hline $\begin{array}{l}\text { Pagamea } \\
\text { guianensis }\end{array}$ & Presente & & Presente & & & & \\
\hline Perama hirsuta & Presente & & & & & Presente & \\
\hline Posoqueria latifolia & & & & & Presente & Presente & \\
\hline $\begin{array}{l}\text { Psychotria } \\
\text { hoffmannseggiana }\end{array}$ & & & & & & Presente & \\
\hline
\end{tabular}

Chave para a identificação das espécies e variedades de Rubiaceae da APA de Algodoal/Maiandeua

1. Estípulas fimbriadas 2

Estípulas não fimbriadas

2. Folhas glabras; cápsula septicida, linear-oblonga a oblonga

Borreria verticillata

Folhas hirsutas; cápsula circuncisa, oblonga, globosa a oval

3. Inflorescências em glomérulos, sésseis; corola branca; estames exsertos, presos na fauce; filete 0,4-0,5 mm de comprimento; ovário bilocular; sementes oblongas, com um sulco longitudinal em forma de ' $Y$ ', superfície reticulada Mitracarpus frigidus var. discolor Inflorescências em espigas, pedunculadas; corola amarela; estames inclusos, presos no tubo próximo à fauce, alternados com os lobos; filete, 0,1 mm de comprimento; ovário bi ou trilocular; sementes piramidais, angulosas, superfície lisa

Perama hirsuta

4. Folhas subsésseis ou sésseis (pecíolo de até $2 \mathrm{~mm}$ ) .......................................................................... 5

Folhas pecioladas (pecíolo $>2 \mathrm{~mm}$ )

5. Folha com acarodomácias; estípulas acuminadas e/ou mucronadas; inflorescência em monocásio; flor subséssil;

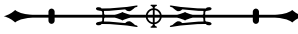


fruto baga; sementes ovais. Tocoyena brasiliensis

Folha sem acarodomácias; estípulas não acuminadas e nem mucronadas; inflorescência em dicásio (cimeira dípara); flor pedicelada; fruto não baga; sementes globosas ou angulosas ... 6

6. Arbusto ou árvore; folhas com nervuras curvivênias; estípulas aristadas; cálice truncado, 4-denteado; fruto drupa; sementes globosas ... Faramea nitida Ervas; folhas uninérveas; estípulas triangulares; cálice não truncado, 4-lobado; fruto cápsula; sementes angulosas Oldenlandia tenuis

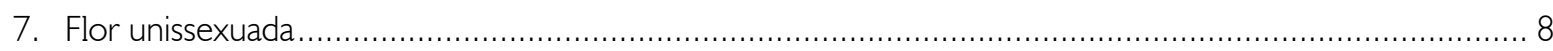

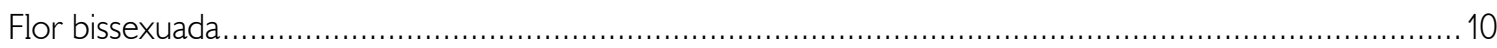

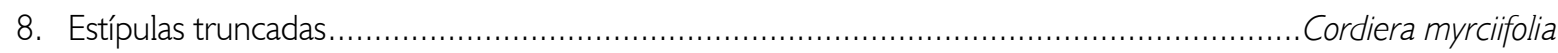

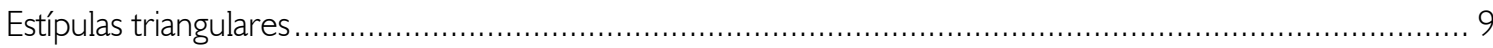

9. Estípulas cônicas, prontamente caducas; velutinas; folhas verticiladas ternas; lâmina foliar obovada a obovadooblonga, 6,5-10 × 4-6 cm; ápice mucronado a obtuso, base cuneada; face abaxial glabra; nervuras curvivênias, 6-7 pares Duroia genipoides Estípulas bilobadas, persistentes, glabras; folhas opostas decussadas; lâmina foliar elíptico-oblonga, até 6-9 x 1,5-3 cm; ápice acuminado a agudo, base aguda; face abaxial com domácias nas axilas das nervuras secundárias; nervuras obliquivênias conspícuas, 11-12 pares Alibertia edulis

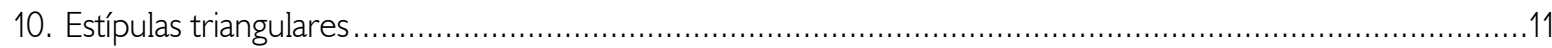

Estípulas bífidas, tubulares, truncadas ou folhosas ................................................................... 14

11. Estípulas glabras; estigma bífido; flores pedunculadas; cálice pentâmero, ovário bilocular ................ 12 Estípulas velutinas; estigma capitado; flores sésseis; cálice truncado; ovário trilocular a plurilocular ......... 13

12. Estípulas com ápice acuminado ou mucronado; inflorescência em racemo; lobos do cálice triangulares; corola campanulada a infundibuliforme

Chiococca nitida

Estípulas com ápice agudo; inflorescência em cima; lobos do cálice arredondados; corola hipocrateriforme Posoqueria latifolia

13. Tubo da corola internamente glabro. Guettarda angelica Tubo da corola internamente velutino Guettarda spruceana

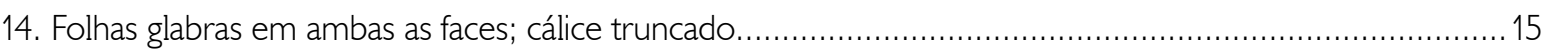

Folhas pilosas em pelo menos uma face; cálice lobulado .............................................................16

15. Estípulas bífidas; inflorescência em glomérulos capituliformes; flores sésseis; corola hipocrateriforme.

Psychotria hoffmannseggiana

Estípulas ovadas, obovadas ou espatuladas, com aspecto de folha; inflorescência em panícula de dicásios; flores pedunculadas; corola infundibuliforme

Psychotria mapourioides

16. Estípulas tubulares, de ápice laciniado; folha com a face adaxial glabra, face abaxial com acarodomácias nas axilas das nervuras secundárias; inflorescência em glomérulos paniculiformes terminais; corola rotácea; ovário bilocular; estigma bífido; fruto superior.

Pagamea guianensis Estípulas truncadas; folha com a face adaxial hirsuta sobre a nervura principal, face abaxial hirsuta sobre as nervuras; inflorescência em espiga; corola hipocrateriforme; ovário pentalocular; estigma com cinco lóbulos triangulares; fruto inferior Retiniphyllum schomburgkii

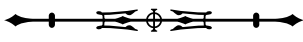


Alibertia edulis (Rich.) A. Rich. ex DC., Prodr. 4: 443. 1830. Figura 1.

Arbusto ca. 3 m de altura. Ramos glabros; entrenós 1,5-4,5 cm de comprimento; estípulas interpeciolares triangulares, glabras, 0,4-0,5 cm de comprimento, ápice agudo. Folhas opostas decussadas; pecíolo glabro 1-1,5 cm de comprimento; lâmina foliar elíptico-oblonga, 6-9x 1,5-3 cm; ápice acuminado ou agudo, base aguda; margem inteira, revoluta; glabra em ambas as faces; nervuras obliquivênias conspícuas, 11-12 pares, com domácias nas axilas das nervuras secundárias. Flor pistilada séssil, terminal; cálice truncado, 3,7 × $2 \mathrm{~mm}$, pubérulo; corola tetrâmera, hipocrateriforme, ca. $1 \mathrm{~cm}$ de comprimento; tubo externamente pubérulo; lobos $8 \times 3 \mathrm{~mm}$. Flor estaminada não observada. Fruto baga, globoso, 3,1 $\times$ 2,4 cm; cálice persistente, superfície pubérula; sementes retangulares, 0,5 ×0,4 cm, superfície estriada.

Distribuição geográfica: México, América Central, Índias Ocidentais, Colômbia, Trinidad-Tobago, Guiana, Suriname, Guiana Francesa, Peru, Bolívia e Brasil (Delprete \& Persson, 2004).

Material examinado: Brasil, Pará: Maracanã, APA de Algodoal/Maiandeua, praia da Princesa, 01/07/1992, L. C. Lobato \& R. Nascimento 484 (MG). Material adicional: Brasil, Amazonas: Manaus, estrada para Itacoatiara, 16/03/1957. G. T. Prance et al. 4651 (MG); Pará: Serra do Cachimbo, 15/02/1977. J. H. Kirkbride \& E. Lleras 2822 (MG); Distrito Federal: borda de uma área pantanosa a um quilômetro de Planaltina, 26/01/1972. J. H. Kirkbride 1696 (F).

Alibertia edulis assemelha-se a A. latifolia (Benth.) K. Schum. pelo mesocarpo seco. A diferenciação entre elas é feita pelas nervuras secundárias, pouco desenvolvidas em $A$. edulis e bem desenvolvidas em $A$. latifolia (Delprete \& Persson, 2004). $\bigcirc$ epíteto específico edulis, em latim, significa comestível (Rizzini \& Rizzini, 1983), confirmando o uso da planta. Os frutos desta espécie são também fonte alimentar de mamíferos e aves silvestres. Além disso, do epicarpo do fruto é extraída uma substância que estimula a produção de leite em mulheres (Forero, 1980).
Popularmente, essa espécie é conhecida, no Brasil, como 'puruzinho', 'puruí-pequeno', 'apuruí' e 'marmelada'; na Guiana Francesa, como 'goyave noire'; no Peru, 'guaiabo'; na Colômbia, 'perita'; e, em Maracaibo, como 'perija' (Cavalcante, 1996). Na APA de Algodoal/Maiandeua, A. edulis encontra-se na formação arbustiva aberta e na mata de Myrtaceae. A espécie foi encontrada frutificando no mês de julho.

\section{Borreria verticillata (L.) G. Mey., Prim. Fl. Esseq. 83. 1818. Figura 2.}

Erva ca. $50 \mathrm{~cm}$ de altura. Ramos glabros; entrenós 0,3-5 cm de comprimento; estípulas interpeciolares 2, 5-fimbriadas, 1-2 mm de comprimento. Folhas opostas decussadas sésseis, com pequenas folhas nas axilas semelhantes à filotaxia verticilada (branquiblastos axilares); lâmina foliar lanceolada, 0,7-2,5 x 0,2-0,5 $\mathrm{cm}$; ápice agudo, base aguda; margem inteira; glabra em ambas as faces; nervuras obliquivênias, três pares. Inflorescência em glomérulos terminais, subterminais e axilares, de 0,6-1 00,6-0,9 cm, sésseis; duas brácteas não involucrais foliáceas glabras, 1-1,5 ×0,3 cm, lanceoladas. Flores andróginas sésseis; cálice 2 laciniado, persistente, hirsuto nas bordas e entre eles, 0,5-1 × 0,5 mm; corola infudibuliforme, tetrâmera, 1-2,5 mm de comprimento; tubo glabro externamente, internamente com um anel de tricomas, na região mediana; lobos glabros, triangulares, 0,5-1 $\times 1 \mathrm{~mm}$; estames 4, exsertos, presos na fauce; filete, $0,5 \mathrm{~mm}$ de comprimento; antera dorsifixa, rimosa, 0,30,4 mm de comprimento; ovário bilocular, uniovulado, óvulos presos ao septo; estilete exserto, 0,5-1 mm de comprimento, glabro; estigma bífido. Fruto cápsula septicida, 1-2,5 $1 \mathrm{~mm}$, linear-oblonga a oblonga, ambas as valvas deiscentes; sementes 0,5-1 0,5 mm, oblongas, elípticas com sulco longitudinal e superfície reticulada.

Distribuição geográfica: África, América Central, Ásia, sudeste dos E.U.A., México, Índias Ocidentais, Colômbia, Venezuela, Guiana, Suriname, Guiana Francesa, Brasil, Paraguai, Uruguai e Argentina (Taylor et al., 2004). 


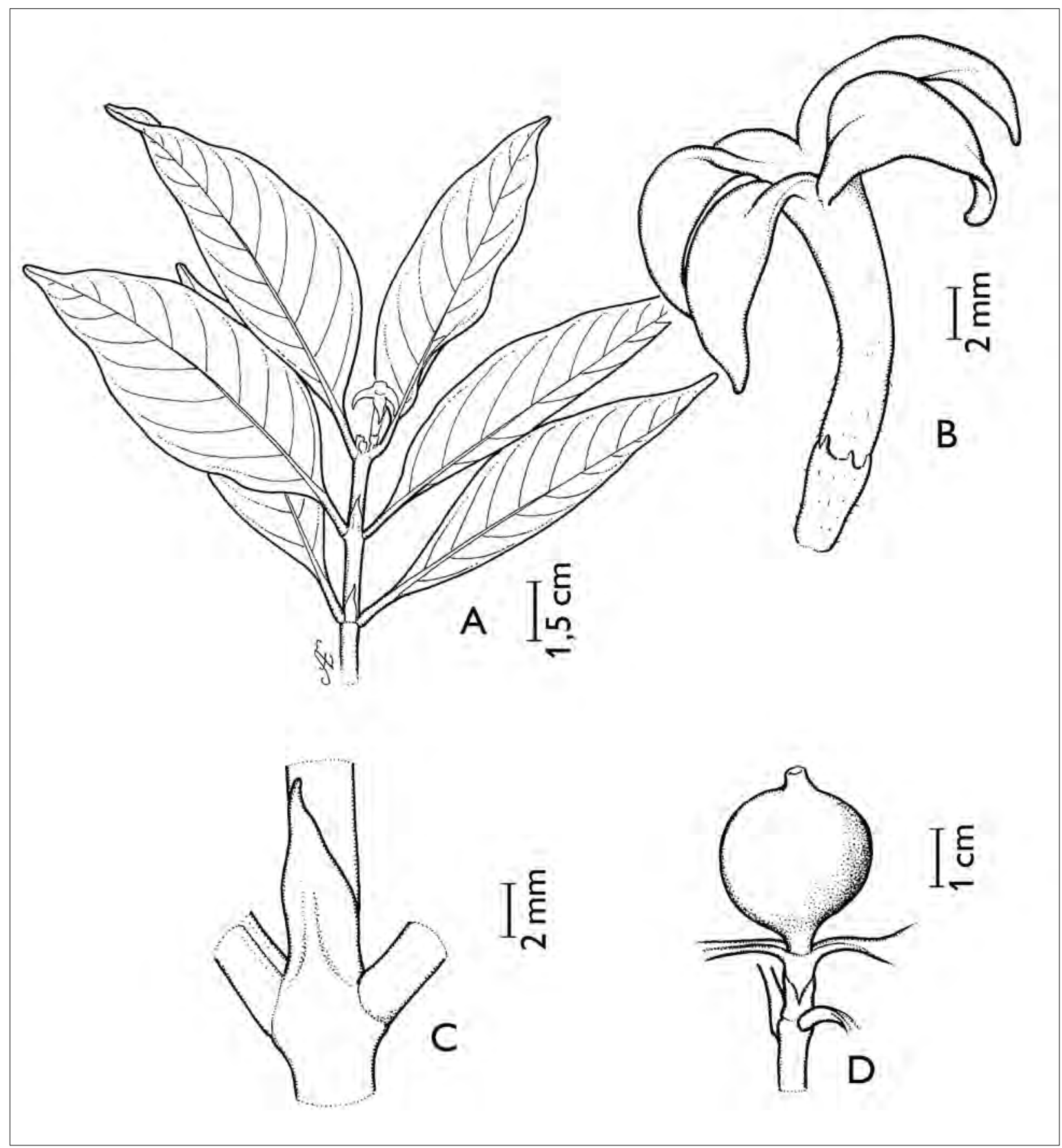

Figura 1. Alibertia edulis (Rich.) A. Rich. ex DC. A. Ramo com flor terminal; B. Flor; C. Estípula; D. Fruto (L. C. Lobato \& R. Nascimento $484-$ MG).

Material examinado: Brasil, Pará: Maracanã, APA de Algodoal/Maiandeua, praia da Princesa, 10/04/1991, M. N. Bastos et al. 819 (MG); ibid. , 23/08/1999, L. Carreira et al. 1400 (MG). gênero Borreria apresenta um conflito de classificação, pois existem estudos, como os de Verdcourt $(1975,1976)$, Burger \& Taylor (1993), Fosberg et al. (1993),

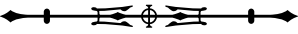




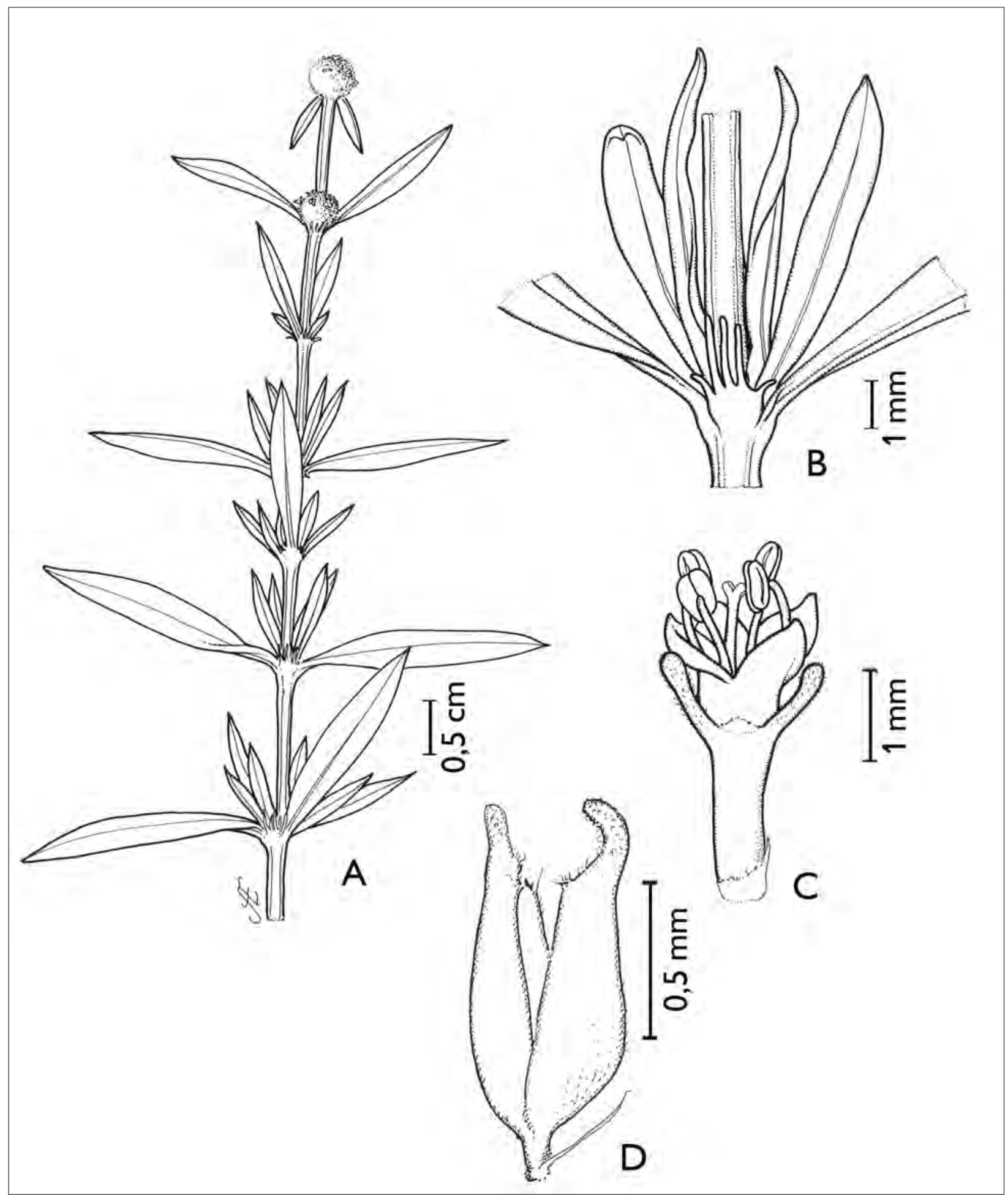

Figura 2. Borreria verticillata (L.) G. Mey. A. Ramo com inflorescência terminal e subterminal; B. Estípula fimbriada; C. Flor; D. Fruto cápsula com ambas as valvas deiscentes (M. N. Bastos et al. 819 - MG).

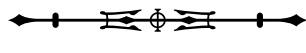


Govaerts (1996) e Mori et al. (2002), que consideram B. verticillata como Spermacoce verticillata $L$. Mesmo assim, as Dras. Elsa Cabral e Nélida Bacigalupo conservam estes gêneros separados pelas características do fruto, mantendo Borreria verticillata (L.) G. Mey. como é tratada neste trabalho.

Borreria verticillata é frequentemente confundida com B. capitata (Ruiz \& Pav.) DC. e B. oligodonta Steyerm., podendo diferenciar-se da primeira pelos lobos do cálice: dois em $B$. verticillata e quatro em $B$. capitata, e da segunda, B. oligodonta, pela proporção entre o tubo da corola, 1,2 $\mathrm{mm}$ de comprimento em $B$. verticillata e $2 \mathrm{~mm}$ de comprimento em B. oligodonta (Steyermark, 1972). No setor agropecuário, $B$. verticillata é conhecida popularmene como 'poaia', sendo uma erva daninha (Gemtchújnicov, 1976; Souza \& Lorenzi, 2005). Como planta medicinal de uso popular, é conhecida como 'vassourinha de botão', sendo utilizadas as folhas e as raízes no tratamento de hemorróidas e varizes (Albuquerque, 1989). Na APA, a espécie, que ocorre no campo entre dunas e no brejo herbáceo, pode ser confundida vegetativamente com Mitracarpus frigidus var. discolor, diferindo pelos lobos do cálice, dois iguais em $B$. verticillata e quatro, iguais dois a dois, em M. frigidus var. discolor. A espécie foi encontrada florescendo e frutificando nos meses de abril e agosto.

\section{Chiococca nitida Benth., J. Bot. (Hooker). 3: 236. 1841. Figura 3.}

Liana ou arbusto sarmentoso. Ramos glabros; entrenós 2-7,5 cm de comprimento. Estípulas interpeciolares triangulares glabras, ápice acuminado a mucronado, 0,1-0,3 $\mathrm{cm}$ de comprimento. Folhas opostas decussadas; pecíolo glabro, 0,3-1,2 cm de comprimento; lâmina foliar ovada a oblongo-lanceolada, 2-10,4 × 0,9-6 cm; ápice agudo a acuminado, base truncada a obtusa; margem inteira; glabra em ambas as faces; nervuras obliquivênias a curvivênias, 5-9 pares. Inflorescência em racemo, 0,8-1,8 cm de comprimento; bractéolas 2-5 laciniadas, 0,5-1 mm de comprimento, tricomas inconspícuos, hialinos nas bordas.
Flores andróginas pediceladas, pubérulas na base, cálice pentâmero, persistente, 2 ×0,5-1 mm; lobos triangulares, 0,5-1 mm de comprimento, com tricomas hialinos entre eles. Corola pentâmera, campanulada a infundibuliforme, ca. $5 \mathrm{~mm}$ de comprimento; tubo glabro externamente, internamente viloso; lobos triangulares glabros, $2 \times 2 \mathrm{~mm}$; estames 5 , inclusos, presos na base do tubo da corola; filete viloso, $1 \mathrm{~mm}$ de comprimento; antera basifixa, rimosa; ovário bilocular, uniovulado; estilete exserto, glabro, 0,3-0,5 cm de comprimento; estigma bífido. Fruto drupa, ovóide, 0,5-0,65 × 0,3-0,4 cm; semente oval a oval-oblonga, $4 \times 3 \mathrm{~mm}$.

Distribuição geográfica: Venezuela, Guiana e Brasil (Taylor et al., 2004).

Material examinado: Brasil, Pará: Maracanã, APA de Algodoal/Maiandeua, vila de Fortalezinha, 01/03/1988, M. N. C. Bastos et al. 539 (MG); 21/12/1993, M. N. C. Bastos et al. 1484 (MG); 22/01/1994, L. C. Lobato 1574 (MG); 05-20/12/1999, L. C. Lobato et al. 2490 (MG).

Chiococca nitida assemelha-se a C. naiguatensis Steyerm. pela inflorescência com 5-21 flores, mas difere pelos lobos do cálice: glabro em C. nitida e piloso em C. naiguatensis. $\mathrm{Na}$ área estudada, a espécie, que ocorre apenas na formação de mata de restinga, caracterizase principalmente por apresentar hábito do tipo liana. Chiococca brachiata Ruiz \& Pav. assemelha-se a C. nitida na forma vegetativa arbustiva e diferencia-se por apresentar no máximo cinco pares de nervuras secundárias, enquanto que em C. nitida são encontrados 5-9 pares. Além disso, a forma do limbo é ovada, com a face abaxial hirsuta em C. brachiata e oblonga, com a face abaxial glabra em C. nitida (Pereira \& Barbosa, 2004). A espécie foi encontrada florescendo em dezembro e frutificando em janeiro.

\section{Cordiera myrciifolia (Spruce ex K. Schum.) C. Persson \& Delprete, in Steyermark et al., Fl. Venez. Guayana 8: 559-560. 2004. Figura 4.}

Arbusto ca. 1,2 m de altura. Ramos glabros, cilíndricos; entrenós 2-5 cm de comprimento; estípulas truncadas, 


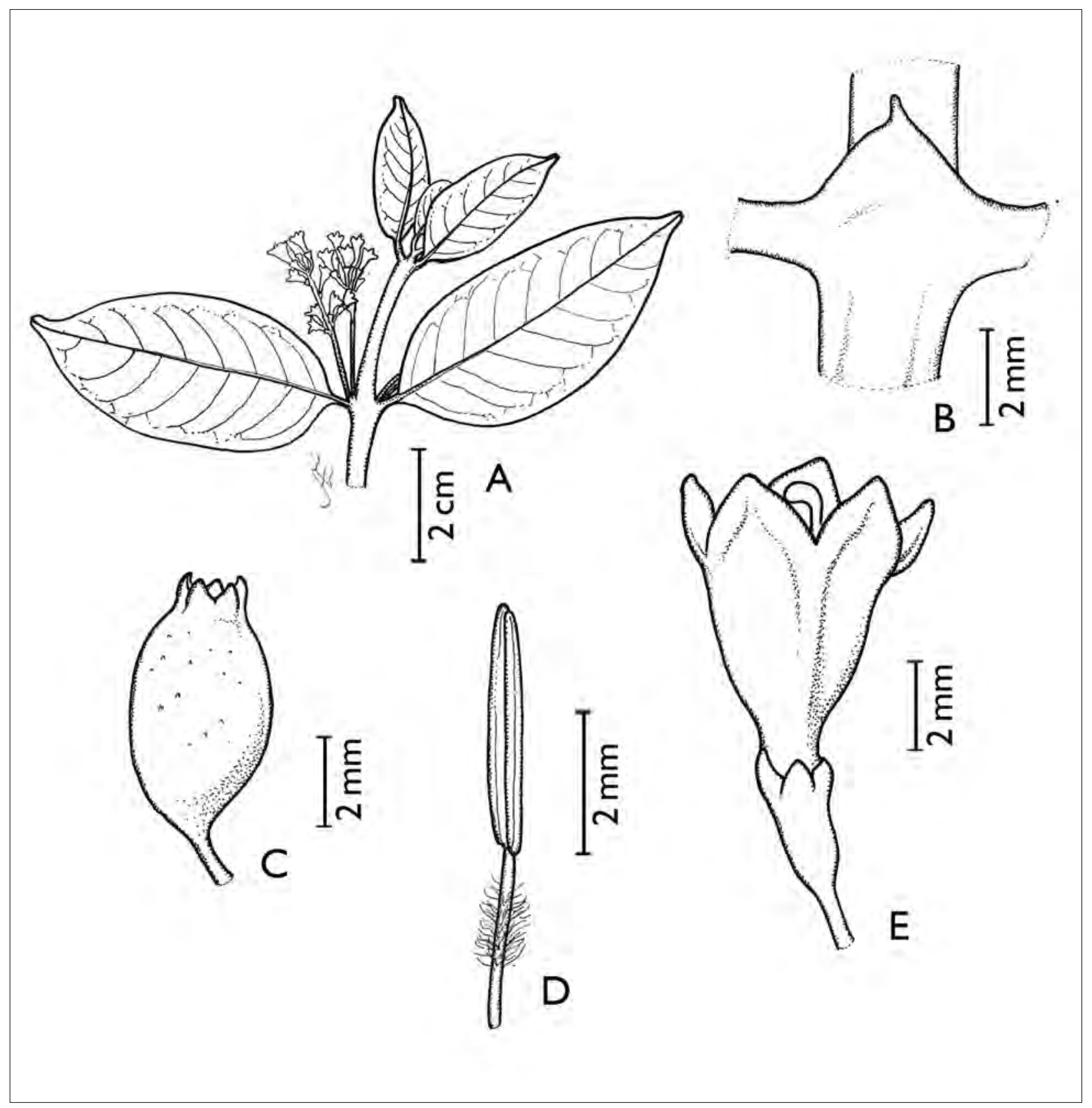

Figura 3. Chiococca nitida Benth. A. Ramo com inflorescência axilar; B. Estípula com ápice mucronado; C. Fruto; D. Estame; E. Flor (M. N. C. Bastos et al. $539-M G)$.

$2,5 \mathrm{~mm}$ de comprimento. Folhas opostas decussadas, pecíolo glabro, 0,4-0,6 cm de comprimento; lâmina foliar obovada, 2,5-9,5 × 1,5-5 cm, ápice acuminado, 0,1-1 cm de comprimento, base aguda; margem inteira revoluta; glabra em ambas as faces; nervuras obliquivênias, 5-8 pares. Inflorescência estaminada em cimas fasciculadas terminais; flores pistiladas solitárias. Flor estaminada; botão floral 7-10 × 1-1,5 mm; cálice 


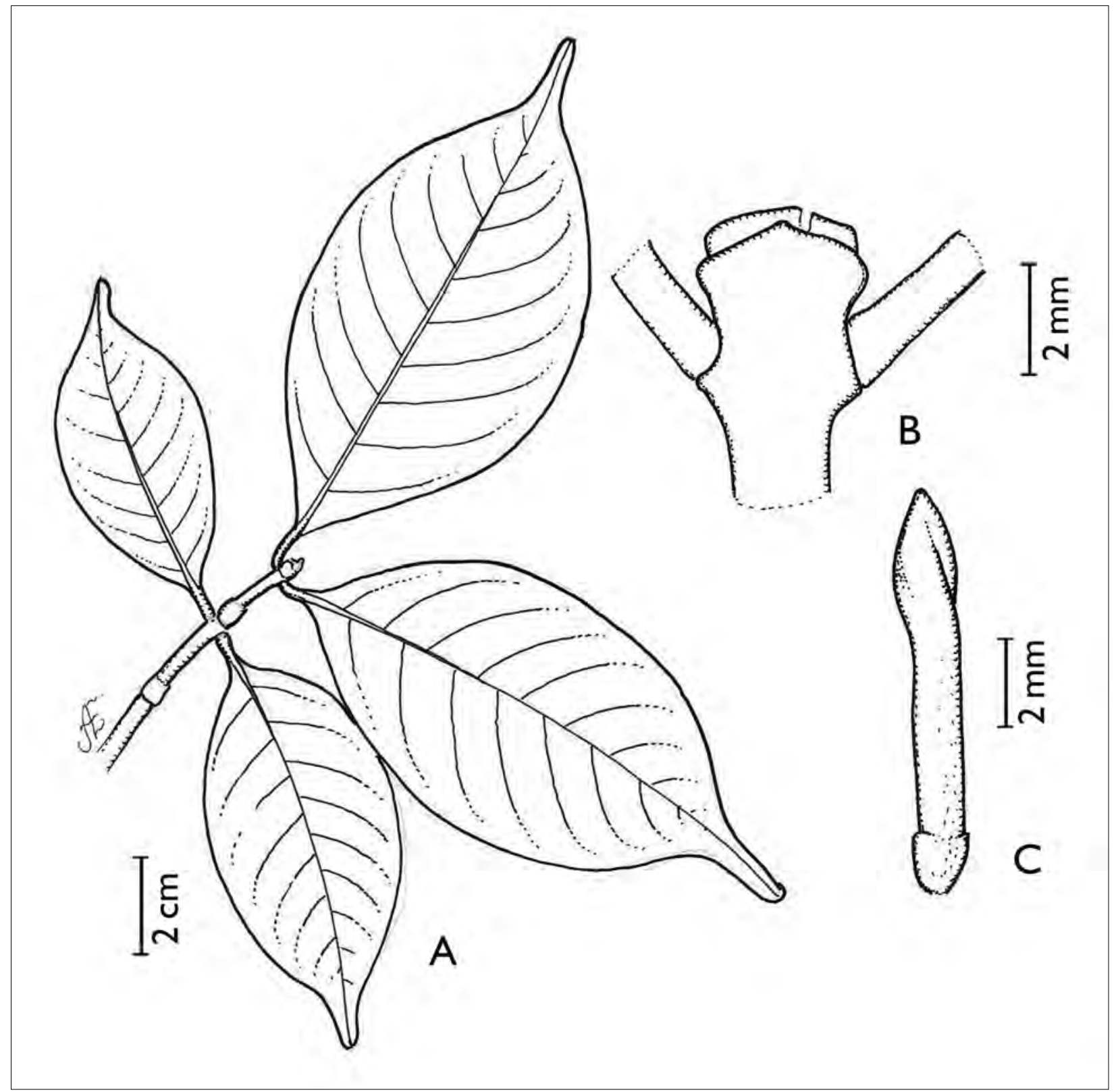

Figura 4. Cordiera myrciifolia (Spruce ex K. Schum.) C. Persson \& Delprete. A. Ramo; B. Estípula truncada; C. Botão floral (M. N. Bastos et al. $596-M G)$.

truncado, 1,1-1,7 × 1,2-1,5 mm, pubérulo, persistente; corola tetrâmera, hipocrateriforme, $0,5-1 \mathrm{~cm}$ de comprimento; tubo externamente velutino, $6-8 \mathrm{~mm}$ de comprimento, internamente glabro; lobos ovados a deltóides, $4 \times 2 \mathrm{~mm}$, face dorsal parcialmente velutina e ventral glabra; estames 4, inclusos, inseridos na base do tubo ou próximos a ela, filiformes; antera dorsifixa, rimosa. Flor pistilada não observada. Fruto baga, globosa, $9 \times 7 \mathrm{~mm}$, pubérula; sementes achatadas, ovais, $3 \times 2 \mathrm{~mm}$.

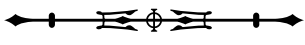


Distribuição geográfica: Panamá, Colômbia, Venezuela, Guiana, Suriname, Guiana Francesa, Brasil e Bolívia (Persson et al., 2004).

Material examinado: Brasil, Pará: Maracanã, APA de Algodoal/Maiandeua, praia da Princesa, 10/10/1990. M. N. Bastos et al. 596 (MG); 11/04/1991, M. N. Bastos et al. 694 (MG); 20-24/09/1994, M. N. Bastos \& L. C. Lobato 1751 (MG). Material adicional: Brasil, Pará: Marajó, Soure, 29/11/1906, R. S. Rodrigues s.n. (MG). Amapá: Curiau-dedentro, ca. 12 km do nordeste de Macapá, 14/11/1979, D. F. Austin et al. 7393 (MG).

Cordiera diferencia-se de Alibertia por apresentar flores pequenas, sendo menor que $10 \mathrm{~mm}$ de comprimento na primeira e maior que $10 \mathrm{~mm}$ de comprimento na segunda (Persson et al., 2004). Alibertia myrciifolia K. Schum. foi transferida para C. myrciifolia por Delprete \& Persson (2004). Cordiera myrciifolia é semelhante a Cordiera triflora A. Rich. ex DC. por apresentar flores e frutos pequenos com o pericarpo carnoso, mas se diferenciam pelo tubo da corola cilíndrico, sem constrições abaixo dos lobos em C. myrciifolia, e tubo cônico, com constrições abaixo dos lobos em C. triflora (Persson et al., 2004). Em Cordiera, as flores estaminadas apresentam cimas fasciculadas terminais, enquanto que as pistiladas apresentam flores solitárias terminais. Na APA, C. myrciifolia pode ser encontrada na mata de Myrtaceae. A espécie foi encontrada florescendo no mês de outubro.

Duroia genipoides Hook. f. ex K. Schum., in Martius, Fl. Bras. 6(6): 364. 1889. Figura 5.

Árvore de $5 \mathrm{~m}$ de altura. Ramos glabros; nós pubérulos; entrenós 0,4-2,5 cm de comprimento. Estípulas cônicas, terminais, velutinas, ápice agudo, $1 \mathrm{~mm}$ de comprimento. Folhas verticiladas, ternadas; pecíolo glabro, 0,6-1,3 cm de comprimento; lâmina foliar obovada a obovado-oblonga, 6,5-10 × 4-6 cm; ápice mucronado a obtuso, base cuneada; margem inteira, glabra em ambas as faces; nervuras curvivênias, 6-7 pares. Flor estaminada com botão floral cônico, viloso na base, $21 \times 5 \mathrm{~mm}$; cálice truncado, $14 \mathrm{~mm}$ de comprimento $\times 0,6 \mathrm{~cm}$ de largura, viloso externamente, seríceo internamente; corola octâmera, $1,3 \mathrm{~cm}$ de comprimento $\times 0,4 \mathrm{~cm}$ de largura; tubo seríceo externa e internamente; lobos lanceolados, $7 \times 2 \mathrm{~mm}$; estames 8 , inclusos, presos na região mediana do tubo, sésseis; antera dorsifixa, rimosa. Flor pistilada com ovário bilocular pluriovulado, com placentação parietal; estilete incluso, 2,5 $\mathrm{mm}$ de comprimento, pubérulo na base; estigma bífido. Fruto baga, 2,2 × 1,2 cm; cálice persistente, globoso, superfície vilosa; sementes auriculares, $5 \times 3,5 \mathrm{~mm}$.

Distribuição geográfica: Venezuela, Guiana e Brasil (Taylor et al., 2004).

Material examinado: Brasil, Pará: Maracanã, APA de Algodoal/Maiandeua, praia da Princesa, 11/04/1991, M. N. Bastos et al. 693 (MG); 20/10/1999, L. C. Lobato et al. 2461 (MG). Material adicional: Brasil, Pará: Mosqueiro, 20/10/1940, A. Ducke 621 (F); 9 km da pista de pouso de Lageira, no rio Maicuru, 28/07/1981, J. J. Strudwick et al. 3876 (IAN); pista de pouso de Sete Varas, rio Curuá, 07/08/1981, J. J. Strudwick et al. 4279 (IAN); pista de pouso de Macau, 24/07/1981, J. J. Strudwick et al. 3486 (IAN); ca. 25 km de Tucuruí, 14/03/1981, Daly et al. 1330 (F); pista de pouso de Sete Varas, no rio Curuá, 10/08/1981, J. J. Strudwick et al. 4468 (MG). Venezuela, Amazonas: rio Negro, 09-14/07/1984, G. Davidse \&J. S. Miller 27319 (F).

Duroia genipoides assemelha-se a $D$. paraensis Ducke por apresentar inflorescência estaminada com 3-4 flores pistiladas, fasciculadas, em pedúnculos longos, mas se diferencia pela pilosidade do pedúnculo das flores pistiladas e do pecíolo, glabros em D. genipoides e esparsamente pilosos em D. paraensis (Steyermark, 1965). O mesmo autor discute ainda o equívoco cometido por Standley (1931), que considerou D. genipoides e D. sprucei Rusby como sendo a mesma espécie. Isso ocorreu devido a uma má interpretação de Standley, que considerou Spruce 3624 (tipo de D. genipoides) como sendo o tipo de D. sprucei, mas, na citação do tipo desta última espécie, constam apenas as coleções Rusby \& Squires 171 e 172. Standley baseou-se em uma publicação de Rusby (1920) que, em sua descrição de $D$. sprucei, indicou, erroneamente, que 


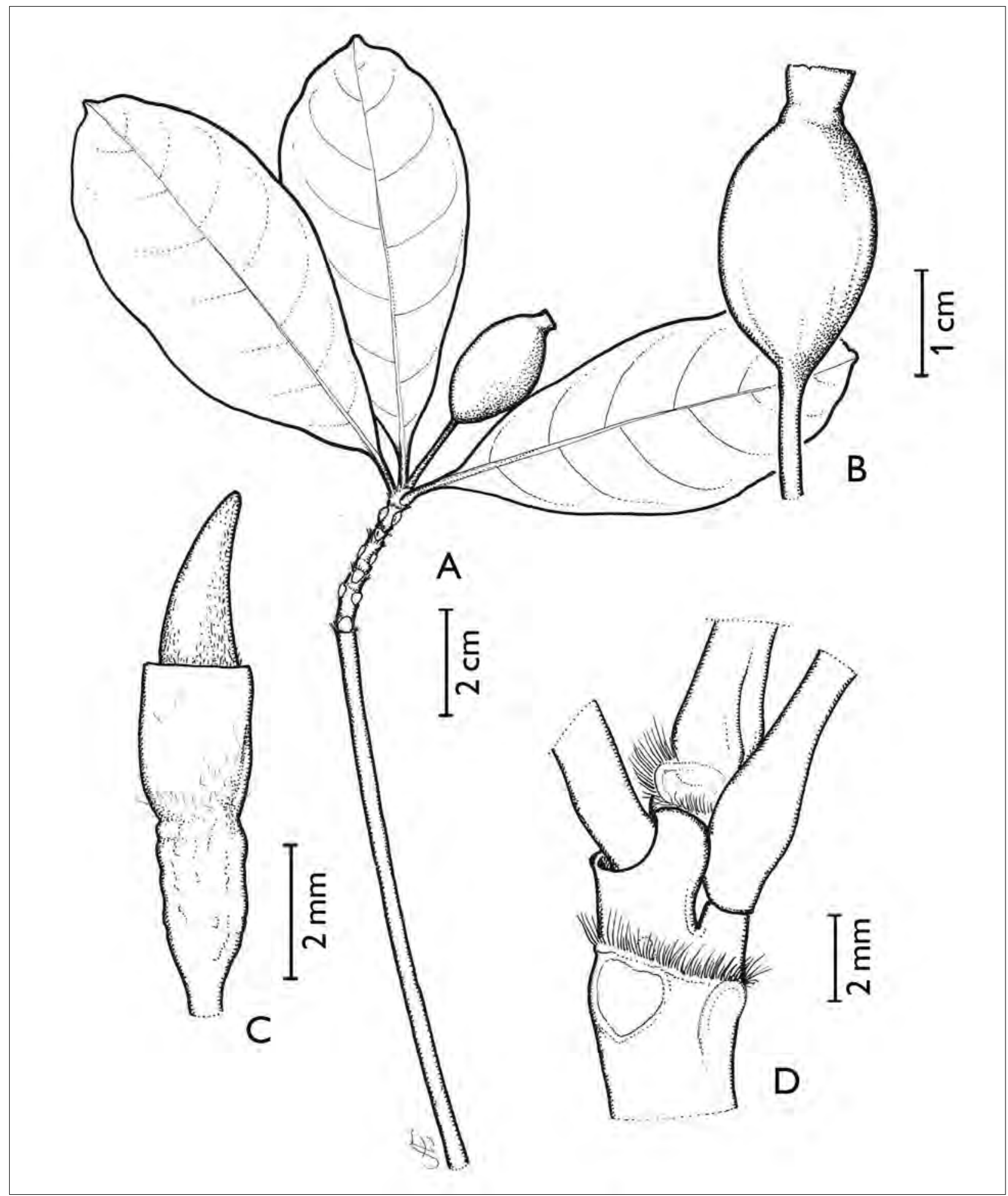

Figura 5. Duroia genipoides Hook. f. ex K. Schum. A. Ramo com fruto; B. Fruto; C. Botão floral; D. Estípula persistente (M. N. Bastos et al. $693-M G)$.

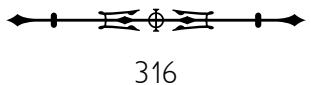


Spruce 3624 era o mesmo tipo dessa espécie. Estas duas espécies diferenciam-se pelo comprimento do pedúnculo das flores pistiladas, longo em $D$. genipoides e séssil em $D$. sprucei (Steyermark, 1965).

Duroia duckei Huber assemelha-se a D. genipoides pelo comprimento do pedúnculo das flores estaminadas (até $13 \mathrm{~mm}$ ) e pela pilosidade do interior do tubo da corola das flores, esparsamente pubérulo a pilosos próximo à base. Diferenciam-se pela pilosidade do interior do cálice, glabro em $D$. duckei e seríceo em $D$. genipoides (Steyermark, 1965). Segundo o Dr. Claes Persson (com. pess.), da Universidade de Göteborg, Suécia, o complexo Duroia duckei - D. genipoides é confuso, e uma revisão detalhada se faz necessária. Estas espécies são muito semelhantes, havendo a possibilidade de serem a mesma. Na APA de Maiandeua, D. genipoides pode ser encontrada na mata de Myrtaceae. A espécie foi encontrada frutificando em abril e florescendo em outubro.

Faramea nitida Benth., Linnaea 23: 454. 1850. Figura 6. Arbusto de 1,3-1,8 m de altura. Ramos glabros; entrenós 1-6,5 cm de comprimento. Estípulas interpeciolares, aristadas, 4-7 mm de comprimento, glabras. Folhas opostas, decussadas, subsésseis; lâmina foliar obovada, obovado-oblonga, oblongo-lanceolada a largamente lanceolada, 2-10,8 x 1-5 cm; ápice mucronado, base aguda; margem inteira, revoluta, conspícua; glabra em ambas as faces; nervuras curvivênias, 5-13 pares. Inflorescência em dicásio terminal, 1,9 × 2,6 cm; pedúnculo $0,8 \mathrm{~cm}$ de comprimento, glabro. Flores andróginas, pediceladas; pedicelo glabro; botões florais cônicos, ápice agudo; cálice truncado, 4-denteado, persistente, $2 \times 2 \mathrm{~mm}$, glabro, com quatro lados; corola pentâmera; tubo 6 × 1-1,5 mm; tubo glabro externa e internamente; estames 5 , inseridos na base do tubo; filete $1 \mathrm{~mm}$ de comprimento; antera dorsifixa, rimosa; ovário bilocular, uniovulado; estilete 2-3 mm de comprimento, glabro; estigma bífido. Fruto drupa globosa, $7 \times 7 \mathrm{~mm}$, glabra; semente globosa, $5 \times 6 \mathrm{~mm}$.
Distribuição geográfica: Brasil (Taylor et al., 2004).

Material examinado: Brasil, Pará: Maracanã, APA de Algodoal/Maiandeua, praia da Princesa, 17/06/1994. M. N. Bastos et al. 1721 (MG); 24/01/1994, L. C. Lobato 1586 (MG); 19-26/06/1991, M. N. Bastos et al. 841 (MG).

Faramea nitida assemelha-se a F. crassifolia Benth., diferenciando-se desta por apresentar folhas subsésseis, pois em F. crassifolia as folhas são pecioladas (Taylor et al., 2004). Na APA de Maiandeua, F. nitida pode ser identificada pelas estípulas interpeciolares aristadas e folhas subsésseis com a margem inteira revoluta, sendo encontrada na formação de mata de Myrtaceae. A espécie foi encontrada florescendo em janeiro e junho e frutificando em junho.

\section{Guettarda angelica Mart. ex Müll. Arg., Flora 58: 450. 1875. Figura 7.}

Arbusto de 1,5-3 m de altura. Ramos glabros a pubérulos; entrenós 0,1-10 cm de comprimento. Estípulas interpeciolares triangulares, velutinas, 2-5 $\mathrm{mm}$ de comprimento. Folhas opostas decussadas; pecíolo pubérulo, 0,1-2 cm de comprimento; lâmina foliar elíptica, ovada, lanceolada, oblonga a obovadooblonga, 2-16 × 1-9,2 cm; ápice agudo, acuminado a mucronado, base aguda a obtusa; margem inteira; face adaxial pubérula, com maior concentração sobre as nervuras principal e secundárias, abaxial velutina; nervuras obliquivênias conspícuas, 6-10 pares. Inflorescência em cima escorpióide, 0,8-3,2 × 0,9-1,5 cm, pubescente a velutina; 1-2 bractéolas lineares, na base de cada flor, 1-4 mm de comprimento, pubescentes a velutinas. Flores andróginas, sésseis; botões florais oblongos, ápice agudo a obtuso; cálice truncado persistente, 1-2 lobado, 1,5-3,5 × 1-2 mm, velutino; lobo agudo; corola hipocrateriforme, 5-6 mera, 8-21 mm de comprimento; tubo velutino externamente, glabro internamente; lobos oblongos, 3-5 x 2-2,5 mm, velutinos na face dorsal e glabros, pubescentes a vilosos na face ventral; estames 5-6, inclusos, insertos no tubo próximo à fauce, sésseis; 


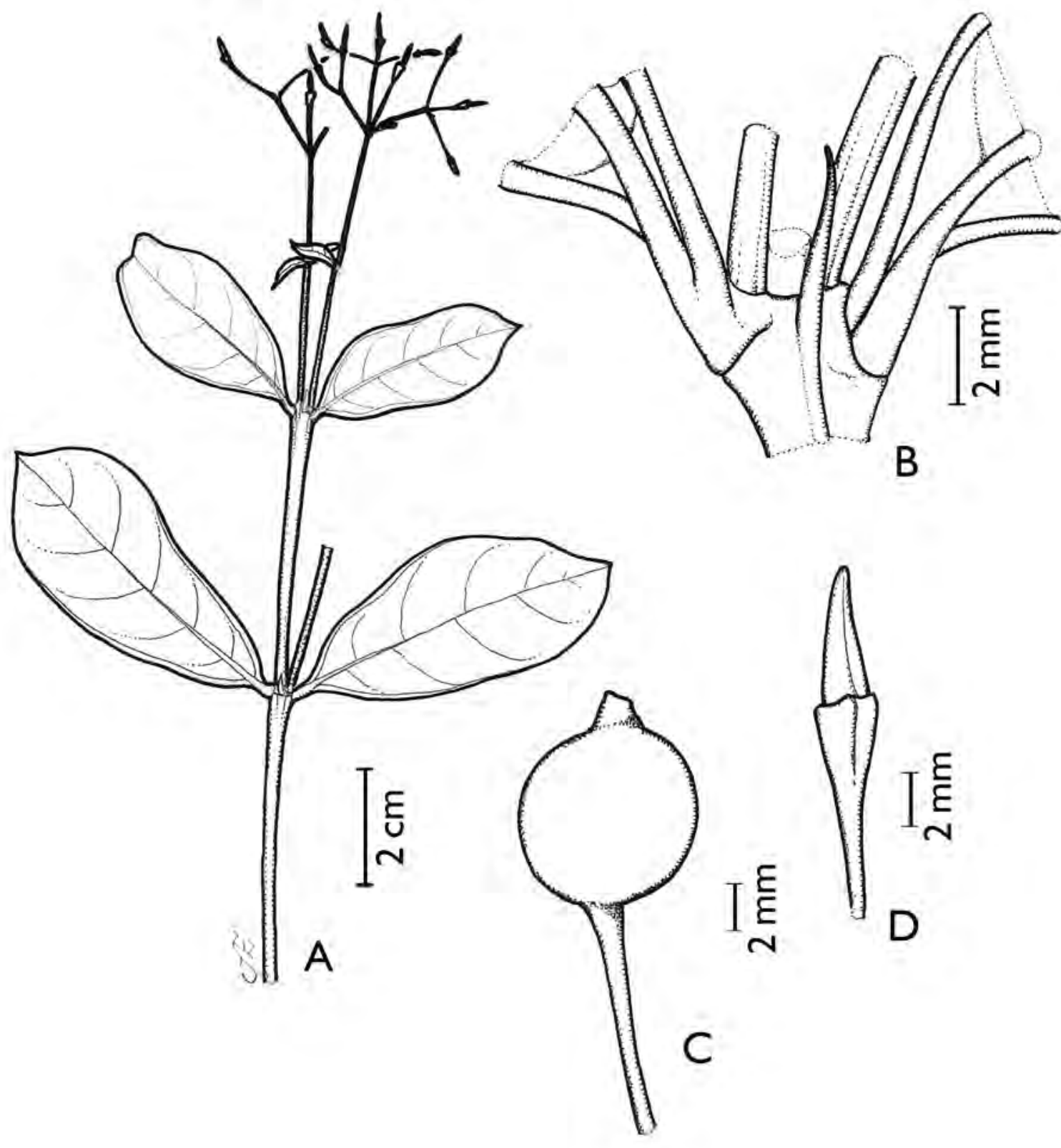

Figura 6. Faramea nitida Benth. A. Ramo com inflorescência terminal; B. Estípula; C. Fruto; D. Botão floral (M. N. Bastos et al. 1721 - MG).

antera dorsifixa, rimosa, 2-3 mm de comprimento; ovário (3-)4(-5) locular, lóculo uniovulado; estilete incluso a exserto, 1,6-18 mm de comprimento, velutino; estigma capitado. Fruto drupa globosa, 3,5-6 × 2,5-6 mm, velutina; pirênios 3-5 loculares.
Distribuição geográfica: Neotropical (Chiquieri et al., 2004).

Material examinado: Brasil, Pará: Maracanã, APA de Algodoal/Maiandeua, praia da Princesa, 30/01/1988, Araújo et al. 8469 (MG); 01/03/1988, M. N. Bastos et

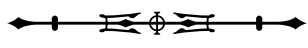




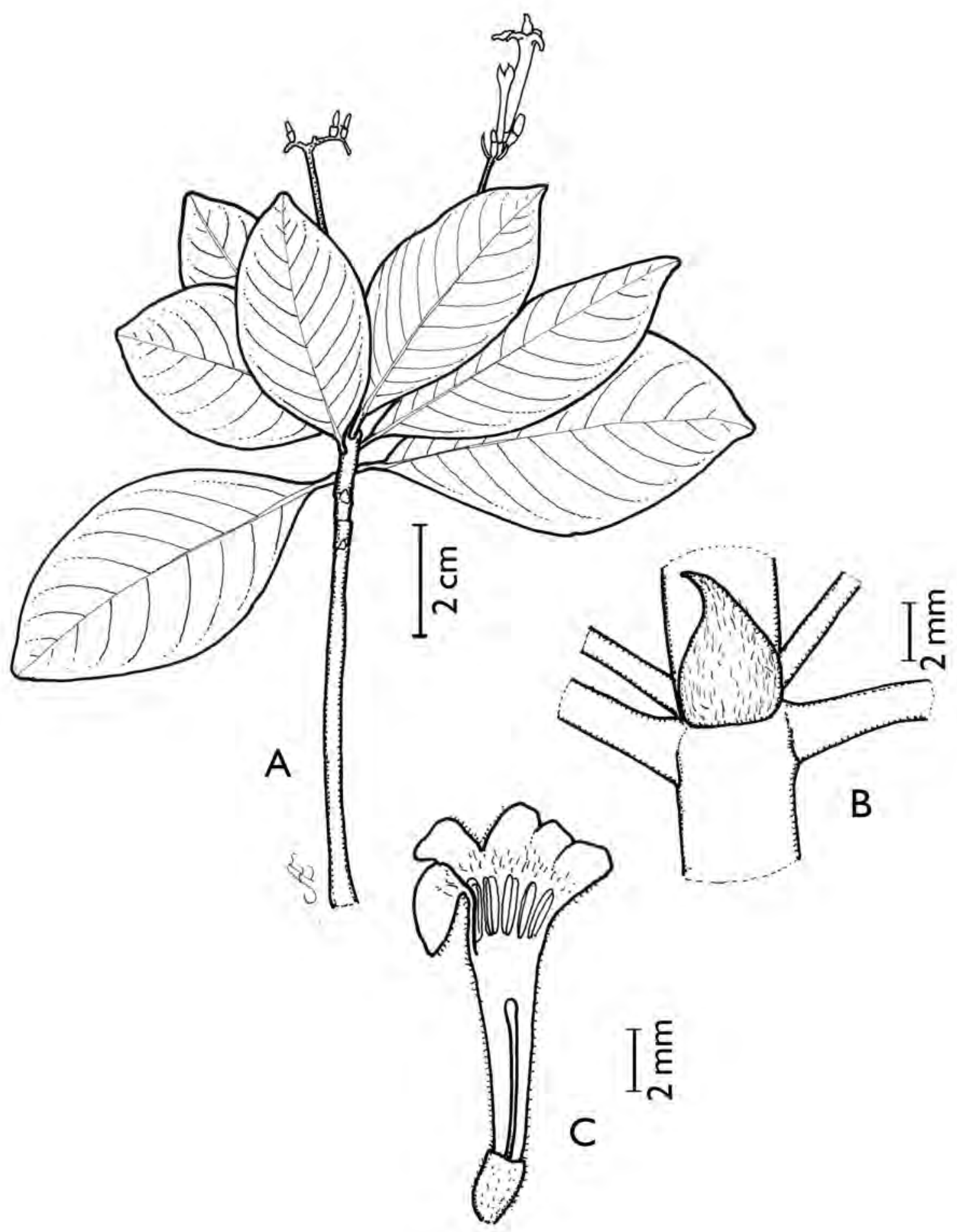

Figura 7. Guettarda angelica Mart. ex Müll. Arg. A. Ramo com inflorescência terminal; B. Estípula; C. Flor, evidenciando o tubo da corola (Araújo et al. 8469 - MG).

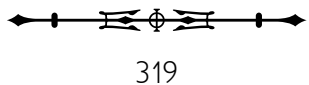


al. 537 (MG); 23/10/1990, M. N. Bastos et al. 631 (MG); 11/04/1991, M. N. Bastos et al. 690 (MG); 12/04/1991, M. N. Bastos et al. 747 (MG); 01/07/1992, L. C. Lobato \& R. Nascimento 469 (MG); 20/12/1993, M. N. Bastos et al. 1516 (MG); 21/02/1993, M. N. Bastos et al. 1538 (MG); praia de Fortalezinha, 22/01/1994, L. C. Lobato 1581 (MG); praia da Princesa, 22/08/1999, L. Carreira et al. 1349 (MG).

Na APA de Maiandeua, G. angelica, que pode ser encontrada sobre as dunas intermediárias e na mata de Myrtaceae, mostra semelhança com G. spruceana Müll. Arg. A diferenciação é feita nos comentários deste último táxon citado. Guettarda angelica ('angélica-do-mato') é utilizada popularmente, na Bahia e no Ceará, para tratamento do tifo, febres e diarreias, como as causadas por salmonelas (salmoneloses). Seus efeitos medicinais foram comprovados por Francisco et al. (2004). A espécie foi encontrada florescendo nos meses de janeiro, abril, agosto, outubro e dezembro e frutificando nos meses de março, abril, julho e agosto.

Guettarda spruceana Müll. Arg., Flora 58: 449. 1875. Figura 8.

Arbusto de $3 \mathrm{~m}$ de altura. Ramos velutinos; entrenós 4-5,5 cm de comprimento. Estípulas interpeciolares triangulares, velutinas, $0,6-0,8 \mathrm{~cm}$ de comprimento. Folhas opostas, decussadas; pecíolo velutino, 0,7-1 cm de comprimento; lâmina foliar ovada a lanceolada, 4-11 x 2-5,5 cm; ápice acuminado, 0,5-1 cm de comprimento, base obtusa; margem inteira; face adaxial pubérula, com maior concentração de tricomas sobre as nervuras principal e secundárias, abaxial velutina; nervuras obliquivênias conspícuas, 6-9 pares. Inflorescência em cima dicotômica, escorpióide, 2,2 × 0,4 cm, velutina; bractéola linear 1, na base de cada flor, 1,5-3 × 0,5 mm, pubescente. Flores andróginas sésseis; botões florais oblongos, ápice agudo a obtuso; cálice truncado, 1-lobado, 2,5 × 1,5 mm, velutino; lobo obtuso; corola hexâmera, hipocrateriforme, 1,6-2,1 cm de comprimento; tubo velutino externa e internamente; lobos oblongos, $3 \times 2 \mathrm{~mm}$, velutinos na face dorsal e vilosos na face ventral, voltada para a fauce; estames 6, inclusos, inseridos próximo à fauce; filete $1 \mathrm{~mm}$ de comprimento; anteras dorsifixas rimosas, 3,5 mm de comprimento; ovário plurilocular, lóculos uniovulados; estilete incluso, $8 \mathrm{~mm}$ de comprimento, velutino; estigma capitado; fruto não observado.

Distribuição geográfica: Venezuela, Suriname e Brasil (Taylor et al., 2004).

Material examinado: Brasil, Pará: Maracanã, APA de Algodoal/Maiandeua, praia de Fortalezinha, 03/07/1992, L. C. Lobato et al. 520 (MG).

Guettarda spruceana assemelha-se a G. macrantha Benth. por ambas apresentarem 8-10 pares de nervuras secundárias, mas se diferenciam pelo comprimento da corola, 18-22 mm na primeira e 55-75 mm na segunda (Taylor et al., 2004). Na APA de Maiandeua, G. spruceana pode ser confundida com G. angelica Mart. ex Müll. Arg., na forma vegetativa, diferenciando-se pela inflorescência e pela pilosidade interna do tubo da corola, sendo dicotômica, com o tubo piloso na primeira, e escorpióide, com o tubo glabro na segunda. A espécie foi encontrada florescendo em julho.

Mitracarpus frigidus (Willd. ex Roem. \& Schult.) K. Schum. var. discolor (Miq.) K. Schum., in Martius, Fl. Bras. 6(6): 82. 1889. Figura 9.

Erva ou arbusto sarmentoso de $40-60 \mathrm{~cm}$ de altura. Ramos glabros a hirsutos; entrenós 1,5-11 cm de comprimento. Estípulas interpeciolares 5-9, fimbriadas, 2-4 mm de comprimento. Folhas opostas, decussadas, sésseis; lâmina foliar elíptico-lanceolada a lanceolada, 1-5,5 x 0,2-1 cm; ápice agudo, base aguda; margem mucronato-serrato; hirsuta em ambas as faces; nervuras obliquivênias, 2-6 pares. Inflorescência em glomérulos terminais e axilares; glomérulos 0,5-1,3 x 0,8-1,4 cm, sésseis, subentendidos por brácteas 2-4 foliáceas, 1,3-4,8 $\times$ 0,2-0,9 cm, estreitamente-lanceoladas a lanceoladas, hirsutas em ambas as faces. Flores andróginas, sésseis, rodeadas por ca. de dez bractéolas; botões florais globosos a oblongos, ápice obtuso; cálice persistente, 


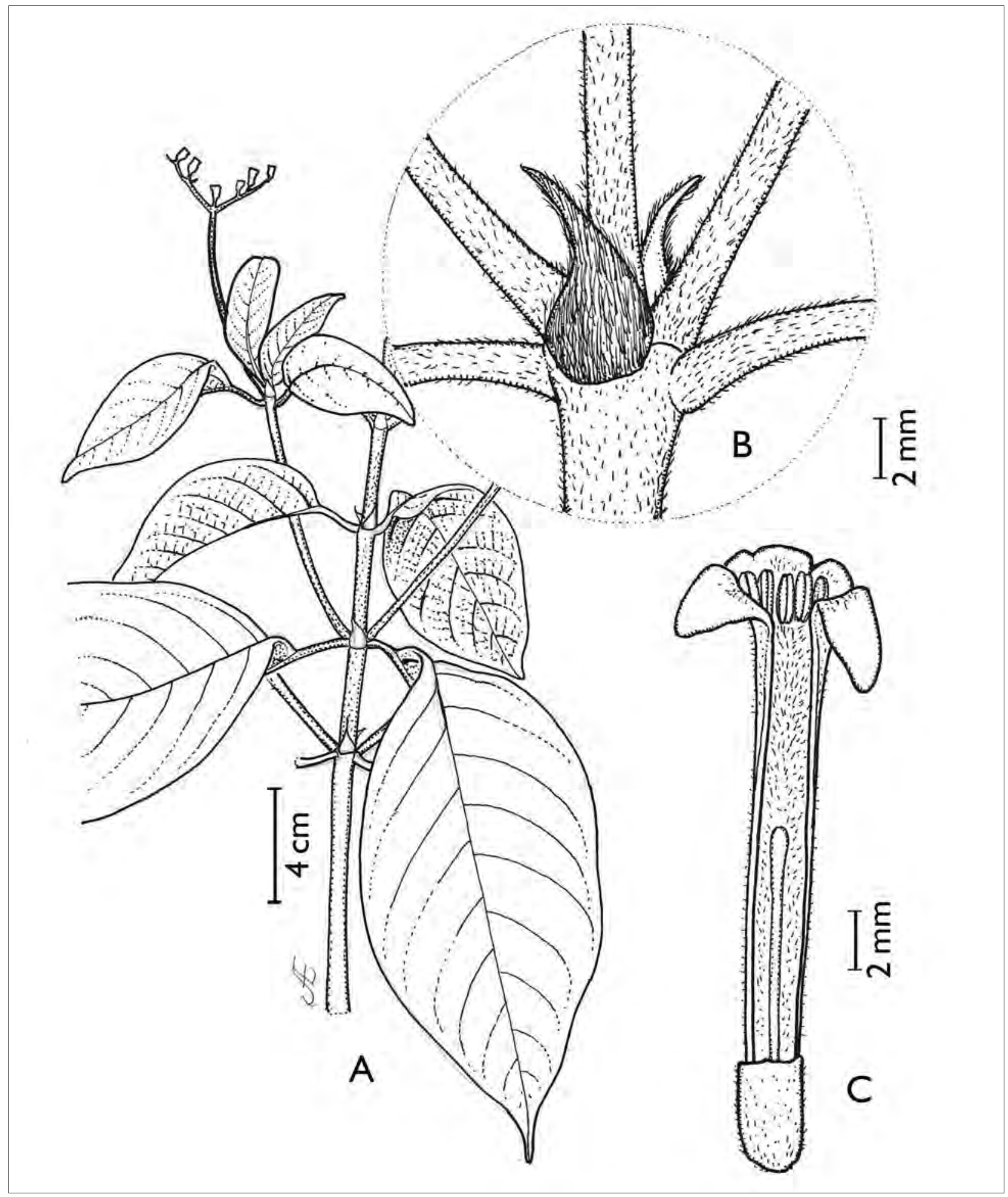

Figura 8. Guettarda spruceana Müll. Arg. A. Ramo com inflorescência; B. Estípula; C. Flor, evidenciando o tubo da corola (L. C. Lobato et al. $520-M G)$.

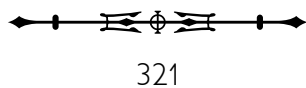




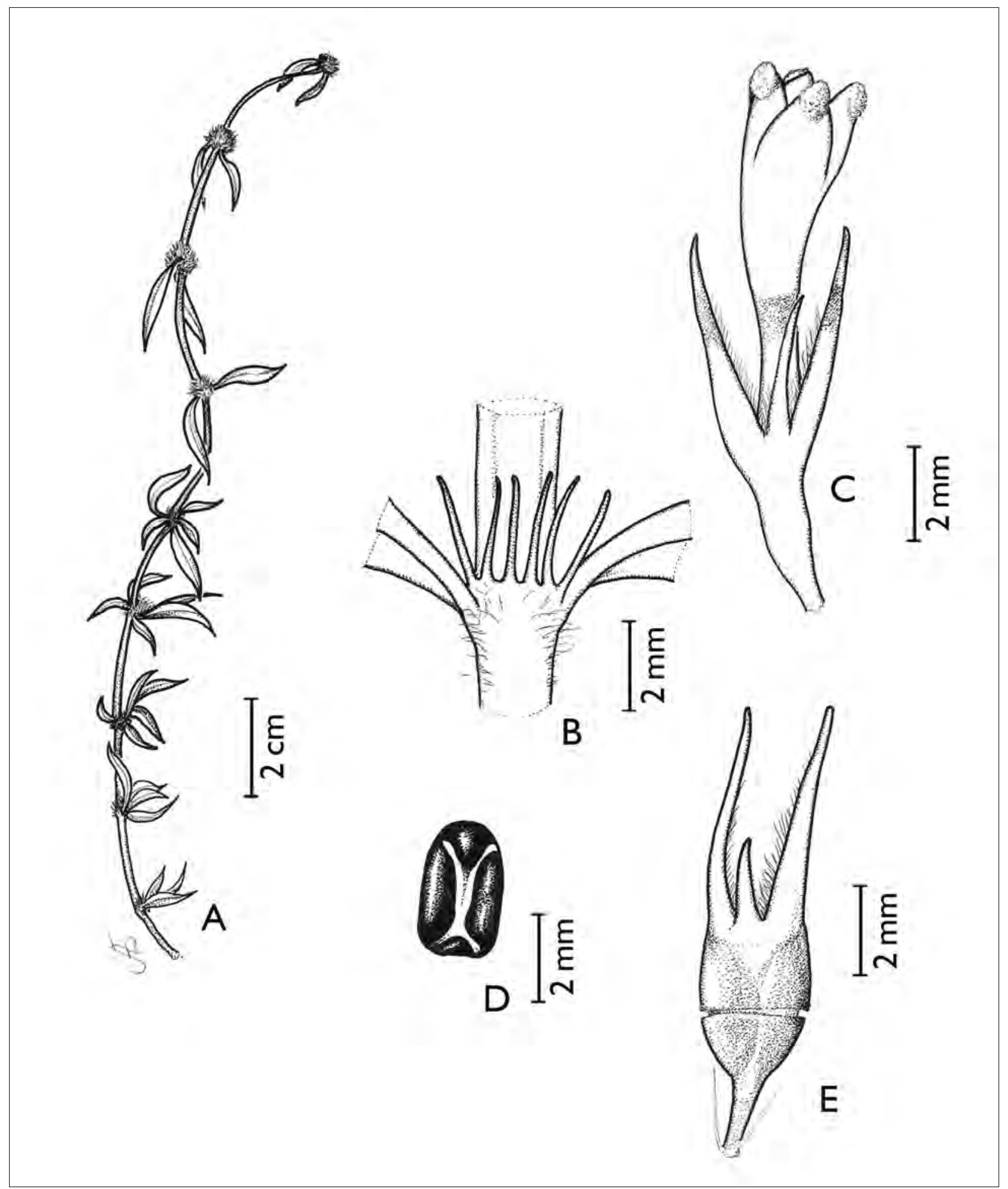

Figura 9. Mitracarpus frigidus var. discolor (Miq.) K. Schum. A. Ramo com inflorescência; B. Estípula; C. Flor; D. Semente - face ventral; E. Fruto (M. N. Bastos et al. $708-$ MG).

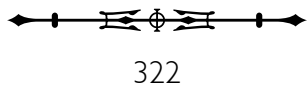


4-laciniado, dois maiores, 1-2 $\mathrm{mm}$ de comprimento, dois menores, 0,5-1 mm de comprimento, hirsutos nas margens; corola infundibuliforme, tetrâmera, 2-4 mm de comprimento; tubo externamente glabro a escabro, com pequenos dentes hialinos sobre o dorso dos lobos, internamente com um anel de tricomas na região mediana do tubo; lobos triangulares, 0,5-1 × 0,5-1 mm; estames 4 , exsertos, inserto na fauce; filete $0,4-0,5 \mathrm{~mm}$ de comprimento; anteras dorsifixas, rimosas; ovário bilocular, uniovulado, placentação axial; estilete exserto, 2-4 mm de comprimento, glabro; estigma bífido. Fruto cápsula oblonga a oval, circuncisa, $3 \times 0,5-1 \mathrm{~mm}$, glabra; semente, 0,5-1 $\times$ 0,2-0,5 mm, oblongas, com um sulco longitudinal em forma de ' $Y$ ', superfície reticulada.

Distribuição geográfica: Neotropical (Andersson, 1992).

Material examinado: Brasil, Pará: Maracanã, APA de Algodoal/Maiandeua, praia da Princesa, 11/04/1991, M. N. Bastos et al. 708 (MG); 12/04/1991, M. N. Bastos et al. 749 (MG); 10/04/1991, M. N. Bastos et al. 817 (MG); 01/07/1992, L. C. Lobato \& R. Nascimento 493 (MG); 01/07/1992, L. C. Lobato \& R. Nascimento 474 (MG).

Mitracarpus frigidus var. discolor assemelha-se a $M$. diffusus (Willd. ex Roem. \& Schult.) Cham. \& Schltdl. e a M. hirtus (L.) DC., pela forma das estípulas, 3-7 fimbriadas, diferenciando-se pelo comprimento da corola, 3,5-6,5 mm em M. frigidus e 1-3 mm em M. hirtus e M. diffusus (Taylor et al., 2004). A posição taxonômica desta variedade ainda está em estudo, segundo o Dr. Elnatan Souza (com. pess.). Provavelmente, em sua tese, o citado pesquisador elevará a variedade à categoria de espécie.

Esta variedade tem preferência por ambientes litorâneos, ocorrendo de norte a sul do país (Pereira \& Barbosa, 2006).

Mitracapus frigidus var. discolor assemelha-se também a Diodia ocymifolia (Willd. ex Roem. \& Schult.) Bremek., Diodia sarmentosa Sw. [recombinada para Diodella sarmentosa (Sw.) Bacigalupo \& Cabral] e Borreria laevis (Lam.) Griseb., apenas vegetativamente, diferindo da primeira pelos lobos do cálice desiguais e pela semente sulcada em forma de ' $Y$ ', enquanto em $D$. ocymifolia os lobos do cálice são iguais e a semente apresenta um sulco longitudinal; a segunda diferencia-se pelo estigma capitado e inflorescência apenas axilar, enquanto que em M. frigidus var. discolor o estigma é bífido e apresentase em glomérulos terminais e axilares; a terceira pode ser distinguida por apresentar os lobos da corola pilosos e um sulco transversal na semente, enquanto que $M$. frigidus var. discolor apresenta lobos da corola glabros e sulco da semente em forma de ' $Y$ '. Na APA de Algodoal/Maiandeua, M. frigidus var. discolor localiza-se no campo entre dunas. A variedade foi encontrada florescendo e frutificando nos meses de abril e julho.

Oldenlandia tenuis K. Schum., in Martius, Fl. Bras. 6(6): 273. 1889. Figura 10.

Erva de 20 cm de altura. Ramos híspidos; entrenós 1,1-1,3 $\mathrm{cm}$ de comprimento. Estípulas interpeciolares triangulares, com tricomas nas bordas, $<1 \mathrm{~mm}$ de comprimento. Folhas opostas decussadas, sésseis; lâmina foliar linear, $1 \times 0,1 \mathrm{~cm}$; ápice agudo, base atenuada; margem híspida; glabra em ambas as faces; uninérvea. Inflorescência em dicásio; duas brácteas foliáceas, com tricomas nas margens, 2-10 × 0,5$1 \mathrm{~mm}$, lineares. Flores andróginas pediceladas; pedicelo glabro, 0,5-1,5 cm de comprimento; cálice tetrâmero, persistente, 0,5 $\times 0,5 \mathrm{~mm}$, lobos triangulares, com tricomas serreados nas bordas, 0,5-1,5 mm de comprimento; corola infundibuliforme, tetrâmera, $2 \mathrm{~mm}$ de comprimento, tubo glabro externa e internamente, lobos oblongos glabros $0,5 \times 0,5 \mathrm{~mm}$; estames 4 , inclusos, presos na parede do tubo da corola, próximo aos lobos; filete, 0,2 mm de comprimento; antera dorsifixa, rimosa; ovário bilocular, pluriovulado; estilete incluso, $1 \mathrm{~mm}$ de comprimento; estigma bífido. Fruto cápsula globosa, $2 \times 2 \mathrm{~mm}$; sementes numerosas, minutas, angulosas, com superfície reticulada.

Distribuição geográfica: Venezuela, Guiana e Brasil (Taylor et al., 2004).

Material examinado: Brasil, Pará: Maracanã, APA de Algodoal/Maiandeua, praia da Princesa, 15/06/1994, M. N. Bastos et al. 1703 (MG). 
Oldenlandia tenuis assemelha-se a $O$. filicaulis $\mathrm{K}$. Schum. pelo hábito herbáceo, da qual se diferencia pelo tipo de ramificação do caule, alternado em $O$. tenuis e oposto em O. filicaulis (Steyermark, 1988). Na APA de Algodoal/Maiandeua, $O$. tenuis foi encontrada no campo entre dunas, sendo um novo registro para a área de estudo. A espécie foi encontrada frutificando em junho.

Pagamea guianensis Aubl., Hist. Pl. Guiane 113, pl. 44. 1775. Figura 11.

Arbusto de 2-2,5 m de altura. Ramos glabros; entrenós 0,1-3 cm de comprimento. Estípulas interpeciolares tubulares, ápice laciniado, 0,5-1 cm de comprimento. Folhas opostas, decussadas; pecíolo glabro, 0,3-1,5 cm de comprimento; lâmina foliar oblanceolada, estreitamente a largamente lanceolada, 2,5-9 × 0,7-3,5 cm; ápice agudo a acuminado, base aguda; margem inteira; face adaxial glabra, abaxial com acarodomácias nas axilas das nervuras secundárias; nervuras secundárias obliquivênias, 4-8 pares. Inflorescência em glomérulos paniculiformes terminais, $1,2-2,5 \times 0,5-1,5 \mathrm{~cm}$, pedunculados, 4,1-6 $\mathrm{cm}$ de comprimento; brácteas 3-laciniadas, 2-4 mm $\times$ 1-2 mm, pubérulas; bractéolas, 1,5-2 x $1 \mathrm{~mm}$, pubérulas nas margens. Flores sésseis; botões florais oblongos a ovais, ápice obtuso; cálice 5-denteado, 1,5-2 × 1-1,5 mm, glabro; lobos triangulares, 1-1,5 × 0,5-1 mm, glabros a pubérulos no ápice; corola tetrâmera rotácea, 0,3-0,4 $\mathrm{cm}$ de comprimento; tubo glabro externamente, velutino internamente; estames 4, exsertos, inseridos na região mediana do tubo; filete, $1 \mathrm{~mm}$ de comprimento; ovário bilocular, lóculos uniovulados, híspido no ápice, entre os septos; estilete incluso, 0,5 mm de comprimento, glabro; estigma bífido. Fruto drupa, globosa, 6-7 ×5-7 mm, glabra, com um sulco longitudinal mediano; semente $6 \times 5 \mathrm{~mm}$, superfície enrugada, com sulcos.

Distribuição geográfica: Venezuela, Guiana, Suriname, Guiana Francesa e Brasil (Vicentini \& Steyermark, 2004).

Material examinado: Brasil, Pará: Maracanã, APA de Algodoal/Maiandeua, praia da Princesa, 01/03/1988, M.
N. Bastos et al. 517 (MG); 11/04/1991, M. N. Bastos et al. 685 (MG); 08/05/1993, M. N. Bastos et al. 1383 (MG); 11/03/1995, L. C. Lobato 1017 (MG). Material adicional: Bolívia, Frederico Roman: oeste do rio Madeira, 8 km ao norte de Nova Esperança, 20/07/2002, J. Urrelo et al. 526 (F). Brasil, Amazonas: boca do rio Içana, Boa Vista (antigo Grilo), 12/09/1987, M. L. Kawasaki 106 (F).

Pagamea guianensis assemelha-se a P. anisophylla Standl. \& Steyerm. pelo pecíolo de 1-2,2 cm de comprimento, e pelas folhas de 2-3,6 cm de largura. Diferencia-se pela pilosidade interna do cálice e externa do ovário. Sendo assim: cálice densamente piloso e ovário glabro em P. anisophylla, e cálice glabro a esparsamente piloso, com ovário híspido no ápice, entre os septos em P. guianensis (Vicentini \& Steyermark, 2004).

Um dos espécimes de $P$. guianensis gerou dúvidas na identificação por assemelhar-se com P. thyrsiflora Spruce ex Benth. pela inflorescência tirsóide, porém difere desta pelo comprimento do pedúnculo, dos lobos do cálice e pela pilosidade do ovário, sendo 1,5-8,3 cm, com lobos 0,5-1,7 $\mathrm{mm}$ e ovário piloso em $P$. guianensis e 0,4-2,8 cm, com lobos 0,1-0,5 mm e ovário glabro em $P$. thyrsiflora (Vicentini \& Steyermark, 2004). Ressaltando ainda as diferenças entre estas duas espécies, o Dr. Alberto Vicentini (com. pess.), especialista no gênero, informou que $P$. thrysiflora tem folhas menores e a inflorescência é, em geral, bem laxa, com poucas flores pediceladas e claramente separadas uma das outras. Já $P$. guianensis possui muitas flores sésseis e densamente agrupadas; os ramos laterais da inflorescência (os mais basais) são geralmente longos em $P$. thyrsiflora, quase tão longos quanto o eixo central e curtos, bem menores que o eixo central em $P$. guianensis. Além disso, $P$. thyrsiflora, em geral, tem flores bissexuadas e homostilas. Ainda segundo o pesquisador, $P$. guianensis é aparentemente dióica (talvez fortemente heterostílica). O material examinado apresenta uma forte heterostilia, pois existe uma considerável diferença no comprimento do estilete em relação à posição das anteras, nas flores longistilas e curtostilas. 


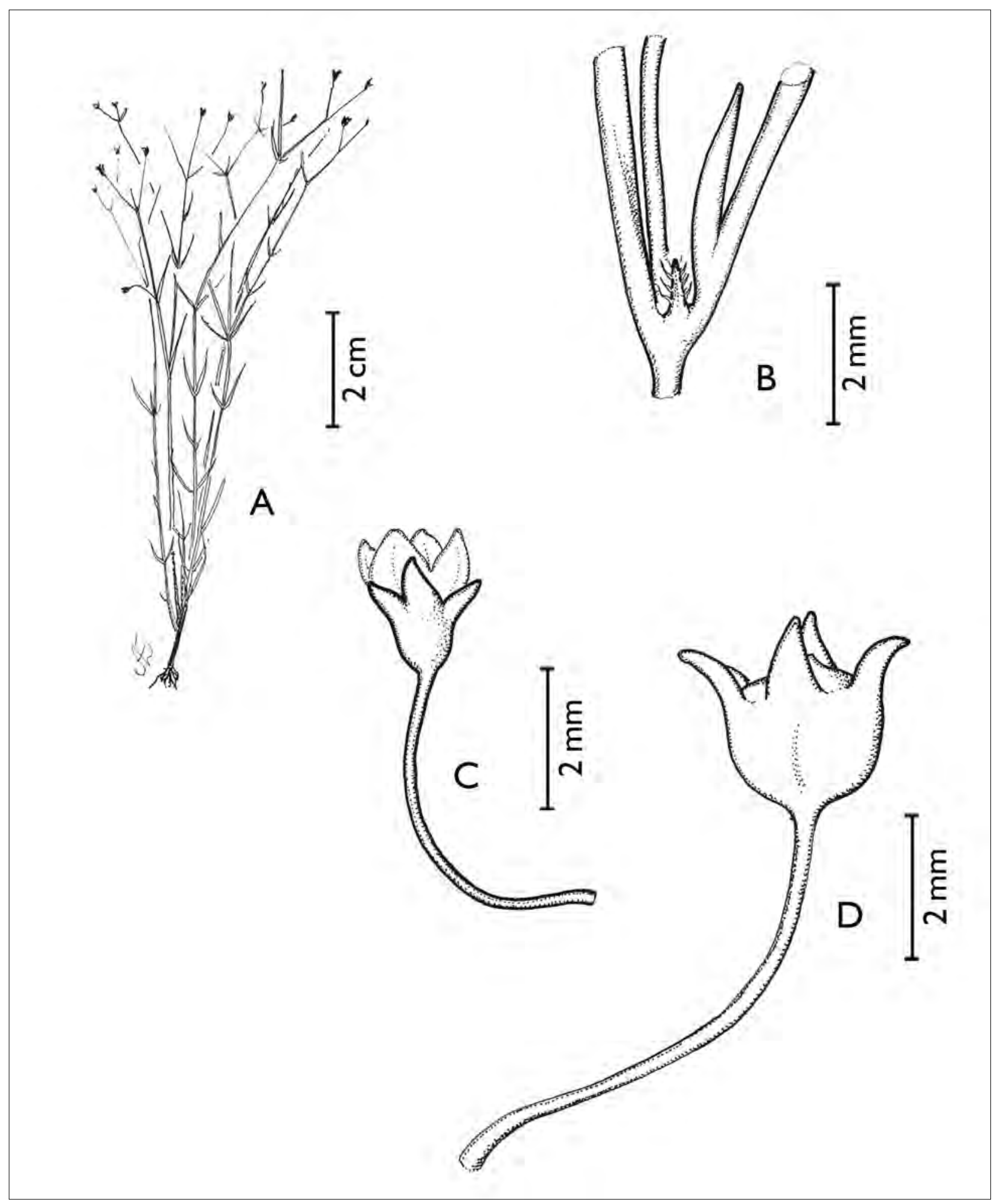

Figura 10. Oldenlandia tenuis K. Schum. A. Ramo com inflorescência; B. Estípula; C. Flor; D. Fruto (M. N. Bastos et al. 1703 - MG).

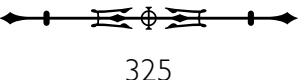




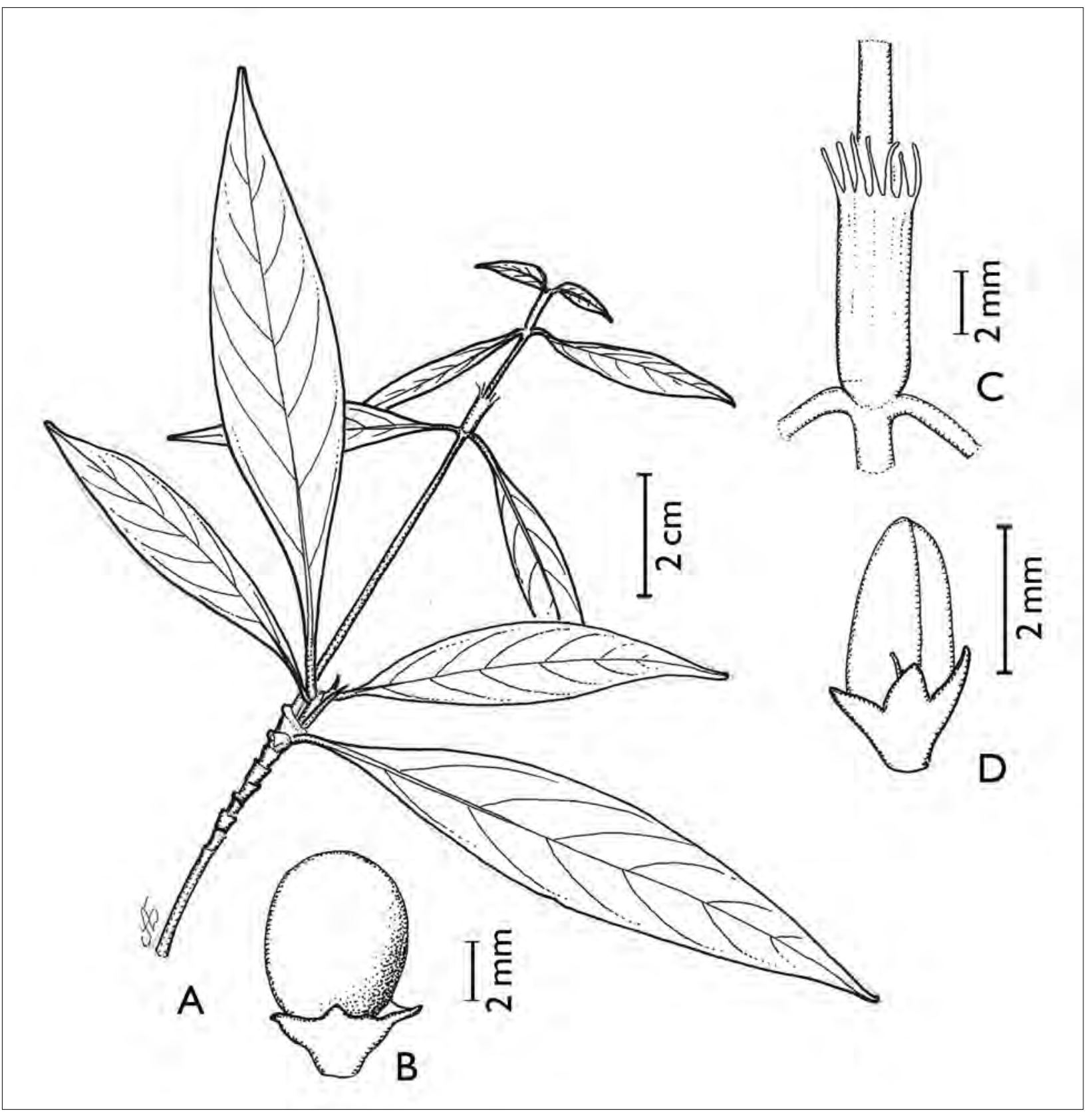

Figura 11. Pagamea guianensis Aubl. A. Ramo; B. Fruto; C. Estípula; D. Botão floral (M. N. Bastos et al. 517 - MG).

Pagamea guianensis é largamente distribuída na Amazônia. Em relação ao ambiente, esta espécie desenvolve-se preferencialmente em áreas de areia branca, sendo também encontrada em florestas de terra firme, de 50 a $400 \mathrm{~m}$ de altitude, florescendo e frutificando durante todo o ano (Boom \& Campos, 1991). Na APA de Algodoal/Maiandeua, P. guianensis pode ser encontrada na formação arbustiva aberta e na mata de Myrtaceae. A espécie foi encontrada florescendo em março e abril, e frutificando em maio.

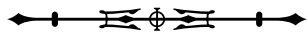


Perama hirsuta Aubl., Hist. Pl. Guiane: 54, pl. 18. 1775. Figura 12.

Erva, subarbusto ou arbusto de $9-30 \mathrm{~cm}$ de altura. Ramos hirsutos; entrenós 0,2-6,5 cm de comprimento. Estípulas interpeciolares reduzidas a uma linha entre as folhas fimbriadas. Folhas opostas, decussadas, sésseis; lâmina foliar lanceoladaovada, 0,3-1,5 × 0,1-0,3 cm de largura; ápice agudo, base obtusa; margem hirsuta; hirsuta em ambas as faces; nervuras quinquenérveas. Inflorescência em espiga, 3-13 × 4-7,5 mm, terminais ou axilares, pedunculadas, hirsutas; pedúnculo 0,152,7 cm de comprimento; brácteas 2-foliáceas, não involucrais, 0,4-0,85 × 0,07-0,15 cm, hirsutas, linear-lanceoladas. Flores andróginas com botões florais ovais a oblongos, ápice agudo a obtuso; cálice 2-laciniado, hirsuto, 1-2,5 × 0,2-0,4 mm; corola infundibuliforme a hipocrateriforme, tetrâmera, 2-5 $\mathrm{mm}$ de comprimento; tubo glabro externamente, viloso internamente, no ponto de inserção dos estames; lobos triangulares, 0,5-1 $\times$ 0,5 mm, pilosos no ápice; estames 4-inclusos, presos no tubo próximo à fauce, alternados com os lobos; filete, 0,1 mm de comprimento, antera dorsifixa, rimosa; ovário trilocular uniovulado; estilete exserto, 3-3,5 mm de comprimento, glabro; estigma bífido. Fruto cápsula, globosa, circuncisa, 0,5-1 ×1 mm, cálice persistente, pubérula a vilosa externamente, na parte superior; semente angulosa, 0,7-1 0 0,5 mm, glabra, piramidal.

Distribuição geográfica: Martinica, Trinidad, Venezuela, Colômbia, Guiana, Suriname, Guiana Francesa, Brasil e Bolívia (Taylor et al., 2004).

Material examinado: Brasil, Pará: Maracanã, APA de Algodoal/Maiandeua, praia da Princesa, 10/10/1990, M. N. Bastos et al. 609 (MG); 19-26/06/1991, M. N. Bastos et al. 839 (MG); 13/06/1994, M. N. Bastos et al. 1685 (MG); 2225/05/1994, M. N. Bastos et al. 1650 (MG); 23/08/1999, L. Carreira et al. 1407 (MG).

Perama hirsuta assemelha-se a $P$. galioides (Kunth) Poir. pelas dimensões da folha, 2-13 x 0,2-4,5 mm, diferenciando-se pela disposição das folhas no caule, verticiladas (3-4 por nó) em $P$. galioides e opostas (raramente ternadas) em P. hirsuta (Taylor et al., 2004). Na
APA de Algodoal/Maiandeua, P. hirsuta pode ser encontrada na formação arbustiva aberta. A espécie foi encontrada florescendo nos meses de maio, junho, agosto e outubro.

\section{Posoqueria latifolia (Rudge) Roem. \& Schult., Syst. Veg. 5: 227. 1819. Figura 13.}

Arbusto de 2 m de altura. Ramos glabros; entrenós 2,6$3,4 \mathrm{~cm}$ de comprimento. Estípulas interpeciolares glabras, triangulares, ápice agudo, $9 \mathrm{~mm}$ de comprimento. Folhas opostas, decussadas, pecioladas; pecíolo glabro, 0,4-1,6 cm de comprimento; lâmina foliar obovada a oblongolanceolada, 5,9-13,8 × 4,3-7,1 cm; ápice mucronado a acuminado, base obtusa a aguda; margem inteira revoluta; glabra em ambas as faces; nervuras obliquivênicas, 4-6 pares. Inflorescência em cima, $12 \times 4,5 \mathrm{~cm}$, terminal, pedunculadas, pubérula; pedúnculo $1 \mathrm{~cm}$ de comprimento; bractéola 1-triangular, 1,5 ×0,5 mm, pubérulas no ápice. Flores andróginas pediceladas; pedicelo glabro, $1,9 \mathrm{~cm}$ de comprimento; botões florais alongados, curvos e ovais no ápice, ápice obtuso; cálice 5-lobulado, $3 \times 4$ mm, glabro; lobos arredondados, ciliados; corola hipocrateriforme, pentâmera, 12,2 × $2 \mathrm{~cm}$; tubo glabro externamente e internamente com tricomas na fauce; lobos oblongos, 1-1,3 $\times$ 0,5-0,6 cm, pubérulos nas bordas; estames 5, exsertos, inseridos na fauce; filete, 3-6 mm de comprimento, antera dorsifixa, rimosa, com tricomas no dorso; ovário bilocular pluriovulado; estilete incluso, 5,3 cm de comprimento, glabro; estigma bífido. Fruto não observado.

Distribuição geográfica: México, América Central, Antilhas, Colômbia, Venezuela, Guiana, Suriname, Guiana Francesa, Equador, Peru, Bolívia e Brasil (Taylor et al., 2004).

Material examinado: Brasil, Pará: Maracanã, APA de Algodoal/Maiandeua, 05/10/2006, M. N. R. Furtado et al. 11 (MG).

Posoqueria latifolia assemelha-se a P. longiflora Aubl. e P. panamensis (Walp. \& Duchass.) Walp. por apresentar a face abaxial da folha glabra, diferenciando-se de ambas pelo comprimento do tubo da corola, 8,5-12 cm em P. latifolia e 18-29,5 cm nas demais (Taylor et al., 2004). No local 


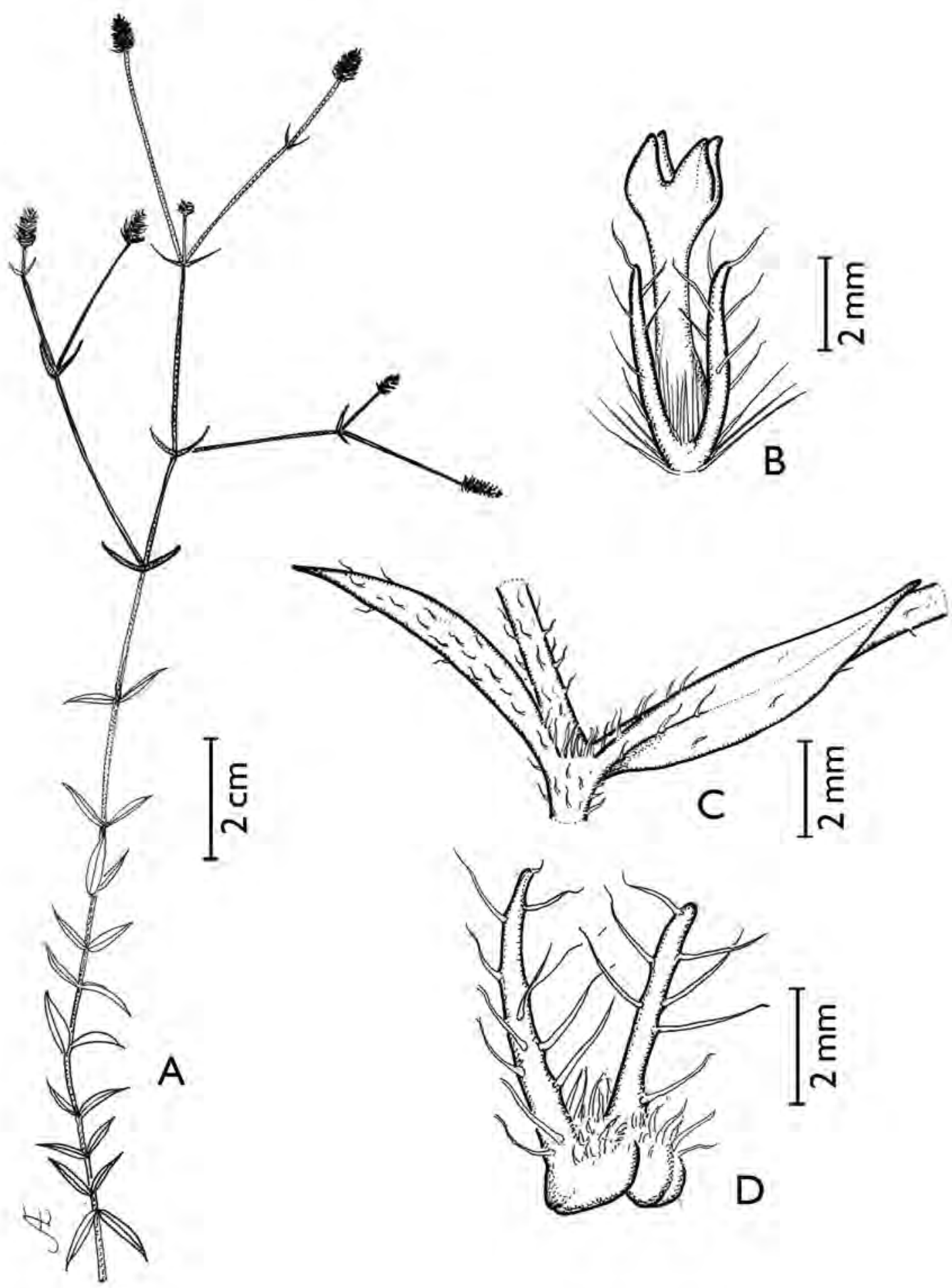

Figura 12. Perama hirsuta Aubl. A. Ramo; B. Flor; C. Estípula; D. Fruto (M. N. Bastos et al. 609 - MG).

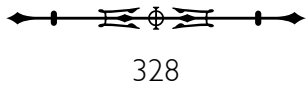




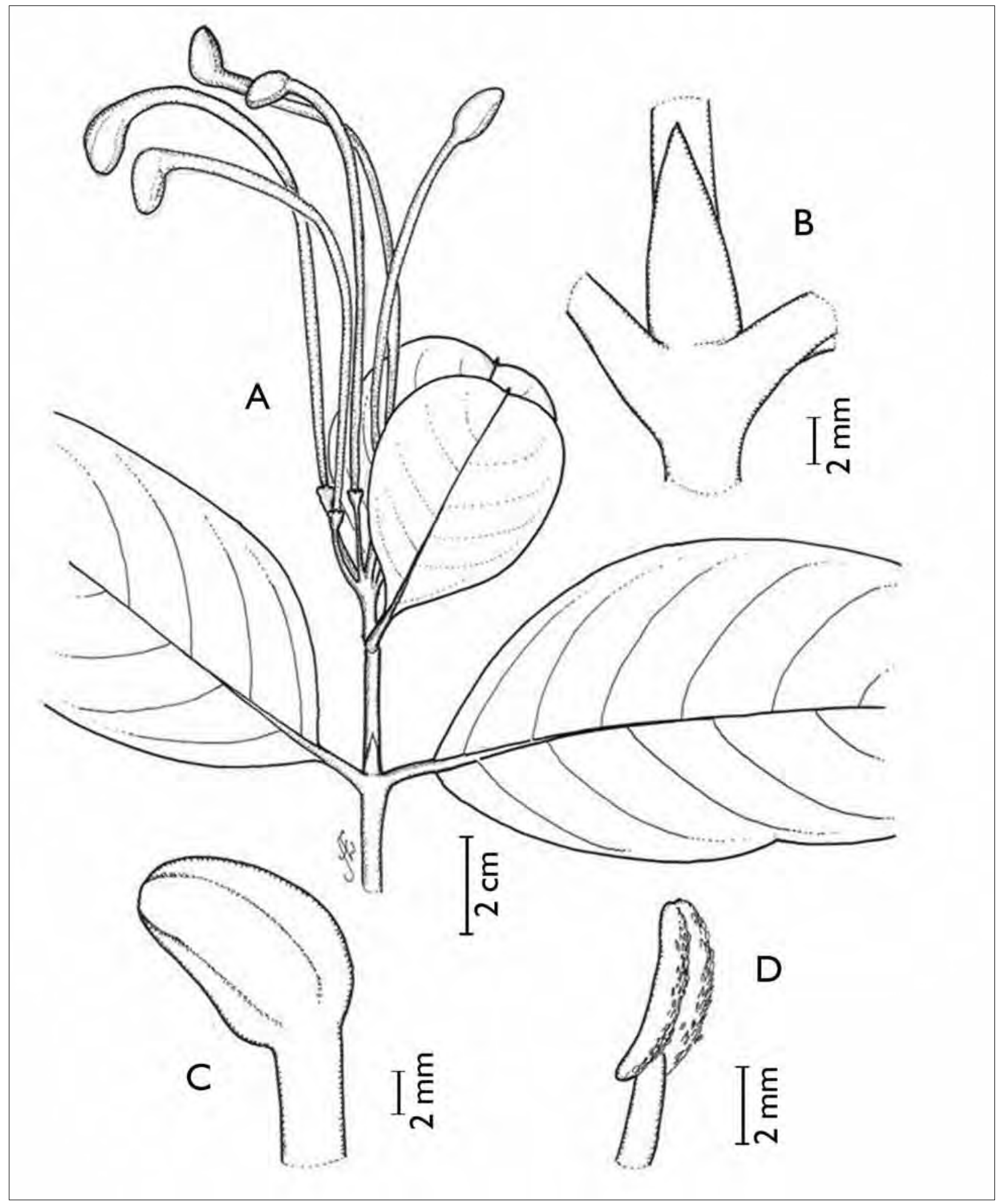

Figura 13. Posoqueria latifolia (Rudge) Roem. \& Schult. A. Ramo; B. Estípula; C. Botão floral; D. Antera. (M. N. R. Furtado et al. 11 - MG).

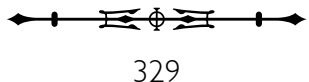


de estudo, P. latifolia pode ser confundida vegetativamente com Tocoyena brasiliensis Mart., diferenciando-se desta pela estípula, pela folha, pelo botão floral e pelo estilete, sendo a estípula aguda, com folha peciolada, botão curvo e obtuso e estilete incluso em $P$. latifolia, e a estípula acuminada a mucronada, com folha subssésil, botão ereto e acuminado e estilete exserto em T. brasiliensis. Posoqueria latifolia é utilizada no tratamento de diarreias (Forero, 1980). Para a APA de Algodoal/Maiandeua, esta espécie, que ocorre na formação de campo entre dunas, é um novo registro. A espécie foi encontrada florescendo no mês de outubro.

Psychotria hoffmannseggiana (Willd. ex Roem. \& Schult.) Müll. Arg., in Martius, Fl. Bras. 6(5): 336. 1881. Figura 14.

Arbusto de 0,7-1,5 m de altura. Ramos glabros; entrenós 2,2-9,8 cm de comprimento. Estípulas interpeciolares bífidas, glabras, 1-2 mm de comprimento. Folhas opostas, decussadas, pecíolo glabro, 0,3-0,6 cm de comprimento; lâmina foliar oval, oblongo-lanceolada a largamente lanceolada, 6,7-12,2 × 2,7-5,6 cm; ápice acuminado, base atenuada; margem inteira; glabra em ambas as faces; nervuras curvivênias conspícuas, 6-8 pares. Inflorescência em glomérulos capituliformes terminais, 1,3-1,5 ×1-1,3 cm, pedunculados, 0,6-1,4 cm de comprimento; 16-21 flores; 6-7 brácteas involucrais, rígidas, 2-9 mm de comprimento $\times 0,5-1 \mathrm{~mm}$ de largura, lineares a estreitamente lanceoladas, face externa pubérula na extremidade e nas bordas, interna, voltada para as flores, glabra; pedúnculo, 0,6 cm de comprimento, pubérulo. Flores andróginas, sésseis; botões florais pubérulos, ovais a oblongos, ápice agudo a obtuso; cálice truncado, 5-denteado, $1 \times 1 \mathrm{~mm}$, com manchas ovaladas, com dentes hialinos na borda, bordo irregular; corola hipocrateriforme, pentâmera, 0,4 cm de comprimento; tubo pubérulo externamente, viloso internamente, do ponto de inserção dos estames até os lobos da corola; lobos triangulares, $1 \times 1 \mathrm{~mm}$, pubérulos externamente, viloso internamente; estames 5 , inseridos na porção mediana do tubo; filete $1 \mathrm{~mm}$ de comprimento; antera dorsifixa, rimosa; ovário bilocular, uniovulado; estilete pubérulo, 2 mm de comprimento; estigma bífido. Fruto uma drupa globosa, $3 \times 4 \mathrm{~mm}$, com sulcos longitudinais, glabra; semente $1 \times 2 \mathrm{~mm}$, plano-convexa, sulcada, glabra.

Distribuição geográfica: América Central, Colômbia, Venezuela, Guiana, Suriname, Guiana Francesa, Equador, Peru, Bolívia e Brasil (Taylor et al., 2004).

Material examinado: Brasil, Pará: Maracanã, APA de Algodoal/Maiandeua, praia da Princesa, 01/03/1988, M. N. Bastos et al. 516 (MG); 10/04/1991, M. N. Bastos et al. 830 (MG); 21/02/1994, M. N. Bastos et al. 1560 (MG). Material adicional: Panamá, Veraguas: costa sul da enseada Santa Cruz, 27/07/1970, R. Foster 1633 (F). Equador, Napo: rio Yasuni, 13/09/1977, R. B. Foster 3625 (F). Peru, Maynas: Pebas, 20/06/1976, J. Revilla 767 (F). Brasil, Bahia (foto do parátipo MO).

Psychotria barbiflora DC. foi considerada como um sinônimo de P. hoffmannseggiana por Taylor et al. (2004). Psychotria hoffmannseggiana assemelha-se a P. casiquiara Müll. Arg. e P. spadicea (Pit.) Standl. \& Steyerm. pelas dimensões das folhas, $2-13 \times 0,5-5 \mathrm{~cm}$, porém, diferencia-se de ambas pelo comprimento das brácteas da inflorescência, duas vezes maior que o capítulo em $P$. hoffmannseggiana, e igual em $P$. casiquiara e $P$. spadicea (Taylor et al., 2004). Steyermark (1972) reconheceu quatro variedades em P. hoffmannseggiana, ou seja, var. tribracteata (Wright ex Griseb.) Steyerm., var. celsa Steyerm., var. hoffmannseggiana (Willd. ex R. \& S.) Müll. Arg. e var. erytrophylla (Müll. Arg.) Steyerm. O táxon ocorrente na APA seria a variedade-tipo que se diferencia das demais pelas brácteas glabras na face interior (Steyermark, 1972). Entretanto, Taylor et al. (2004) não reconheceram estas variedades, pois as características utilizadas para separá-las, como a forma do limbo e a pilosidade, são variáveis e não distintivas. Além disso, a var. erythrophylla apresenta o pedúnculo da inflorescência com 15-40 mm de comprimento, característica que põe em dúvida a posição taxonômica desta variedade em relação a P. hoffmannseggiana, que apresenta o pedúnculo de 2-12 $\mathrm{mm}$ de comprimento. 


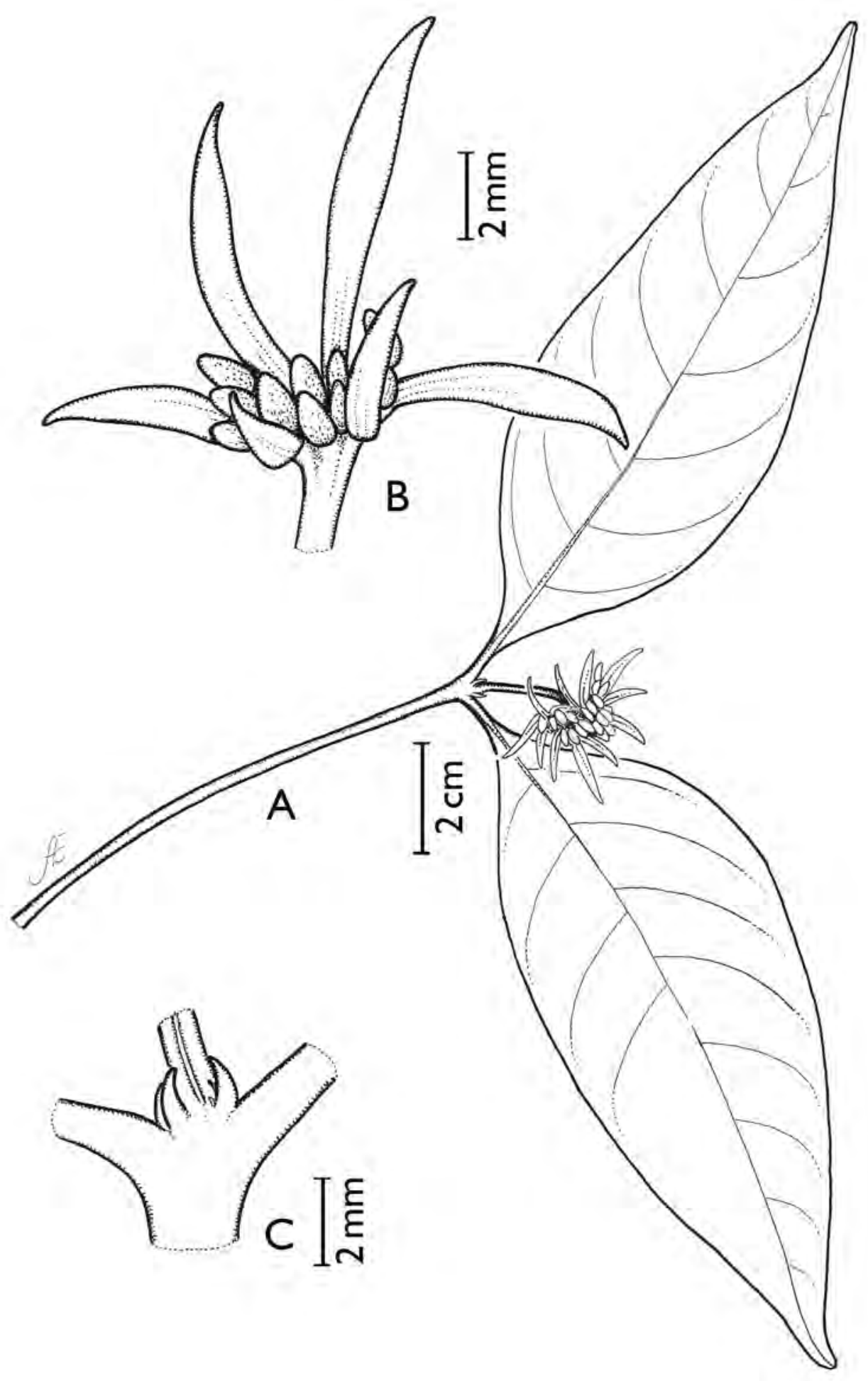

Figura 14. Psychotria hoffmannseggiana (Willd. ex Roem. \& Schult.) Müll. Arg. A. Ramo; B. Inflorescência; C. Estípula (M. N. Bastos et al. 516 - MG).

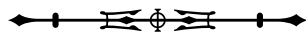


Na América do Sul, P. hoffmannseggiana é largamente distribuída. Em relação ao ambiente, a espécie é encontrada em uma grande variedade de habitats, de 100 a $1.500 \mathrm{~m}$ de altitude, florescendo e frutificando o ano inteiro (Boom \& Campos, 1991).

Na APA de Algodoal/Maiandeua, a espécie pode ser encontrada na formação arbustiva aberta e na mata de Myrtaceae, apresentando um grande número de indivíduos no sub-bosque da mata. A espécie foi encontrada florescendo nos meses de fevereiro e março e frutificando em abril.

\section{Psychotria mapourioides DC., Prodr. 4: 509. 1830.} Figura 15.

Arbusto ou arvoreta de 1,6-3 m de altura. Ramos glabros; entrenós 0,5-6,5 cm de comprimento. Estípulas interpeciolares glabras, terminais, com aspecto de folha, 0,5-1,5 cm de comprimento. Folhas opostas, decussadas; pecíolo glabro, 0,4-1,5 cm de comprimento; lâmina oval, largamente lanceolada, lanceolada-oval a oblongolanceolada, 4,5-14,5 ×2,5-8 cm; ápice agudo a acuminado, base aguda a obtusa; margem inteira revoluta; glabra em ambas as faces; nervuras curvivênias a obliquivênias, 5-9 pares. Inflorescência em panícula de dicásios, 1,2-3,5 x 0,6-2,6 cm, pubérula; bractéolas triangulares, 0,5-1 $x$ 0,5-1 mm, pubérulas, caducas; pedúnculo 2,3-11,2 cm de comprimento. Flores andróginas, pediceladas; pedicelo pubérulo 0,5-2,5 mm de comprimento; botões florais ovais, globosos a oblongos, ápice agudo a obtuso; cálice truncado persistente, 5-6-denteado, 0,5-2 x 1-2 mm, pubérulo; corola pentâmera, infundibuliforme, 1,5-5 mm de comprimento; tubo pubérulo externamente, viloso internamente, do ponto de inserção dos estames até a fauce; lobos oblongos a triangulares, 1-2,5 x 0,5-1 mm, pubérulos; estames 5 , inclusos, presos próximo à fauce; filete 0,1-1 $\mathrm{mm}$ de comprimento; anteras dorsifixas, 0,8-1,3 mm de comprimento, rimosas; ovário bilocular, uniovulado; estilete exserto glabro a pubérulo, na região mediana, 0,9-6 mm de comprimento; estigma bífido. Fruto drupa, obovada, 5 × 3-4 mm, glabra; pirênios plano-convexos, 3,5-4,7 × 2-3 mm, com quatro sulcos longitudinais na face dorsal e dois na face ventral, glabros.

Distribuição geográfica: Trinidad e Tobago, Colômbia, Venezuela, Guiana, Suriname, Guiana Francesa, Equador, Peru, Bolívia e Brasil (Taylor et al., 2004).

Material examinado: Brasil, Pará: Maracanã, APA de Algodoal/Maiandeua, praia da Princesa, 10/10/1990, M. N. Bastos et al. 597 (MG); 23/10/1990, M. N. Bastos et al. 622 (MG); 23/10/1990, M. N. Bastos et al. 678 (MG); 11/04/1991, M. N. Bastos et al. 829 (MG); 03/02/1992, L. C. Lobato et al. 460 (MG); 08/05/1993, M. N. Bastos et al. 1381 (MG); 12/04/1996, M. C. Ferreira 221 (MG). Material adicional: Brasil, Distrito Federal: cerrado, entre Taguatinga e Brasilândia, 1.100 m, 23/02/1966. H. S. Irwin et al. 13107 (F); Peru, Oxampa: Palcazu Valley, Iscozacin, 22/01/1984, R. B. Foster 7972 (F).

Mapouria foi sinonimizado em Psychotria desde 1791. Candolle, analisando Mapouria guianensis Aubl., observou que se tratava de uma espécie do gênero Psychotria. Entretanto, como o epíteto guianensis havia sido ocupado por Psychotria guianensis (Aubl.) Raeusch., desde 1797, então atribuiu-lhe o epíteto mapourioides (Steyermark, 1972).

Psychotria mapourioides assemelha-se com Psychotria yavitensis Steyerm. pelas dimensões do cálice, 0,5-1,2 mm de comprimento, e do tubo da corola, 2,5-5,5 mm de comprimento, diferenciando-se pelas nervuras secundárias e pelo comprimento do pedúnculo da inflorescência, sendo 6-15 pares, com pedúnculo de 2,8-13 cm em $P$. mapourioides e cinco ou seis pares, com pedúnculo de 2,2-4,5 cm em P. yavitensis (Taylor et al., 2004).

Mapouria colarensis Müll. Arg. necessita de um estudo para que, possivelmente, seja sinonimizada no futuro. Psychotria carthagenensis Jacq. assemelha-se com P. mapourioides pelo tipo de inflorescência em panículas terminais e pela corola branca, diferenciando-se pelo comprimento do pedúnculo da inflorescência e pela forma do limbo, sendo 3,5-6 cm, com limbo obovado em $P$. carthagenensis e 2,8-13 cm, com limbo largamente lanceolado em $P$. mapourioides (Taylor et al., 2004). 


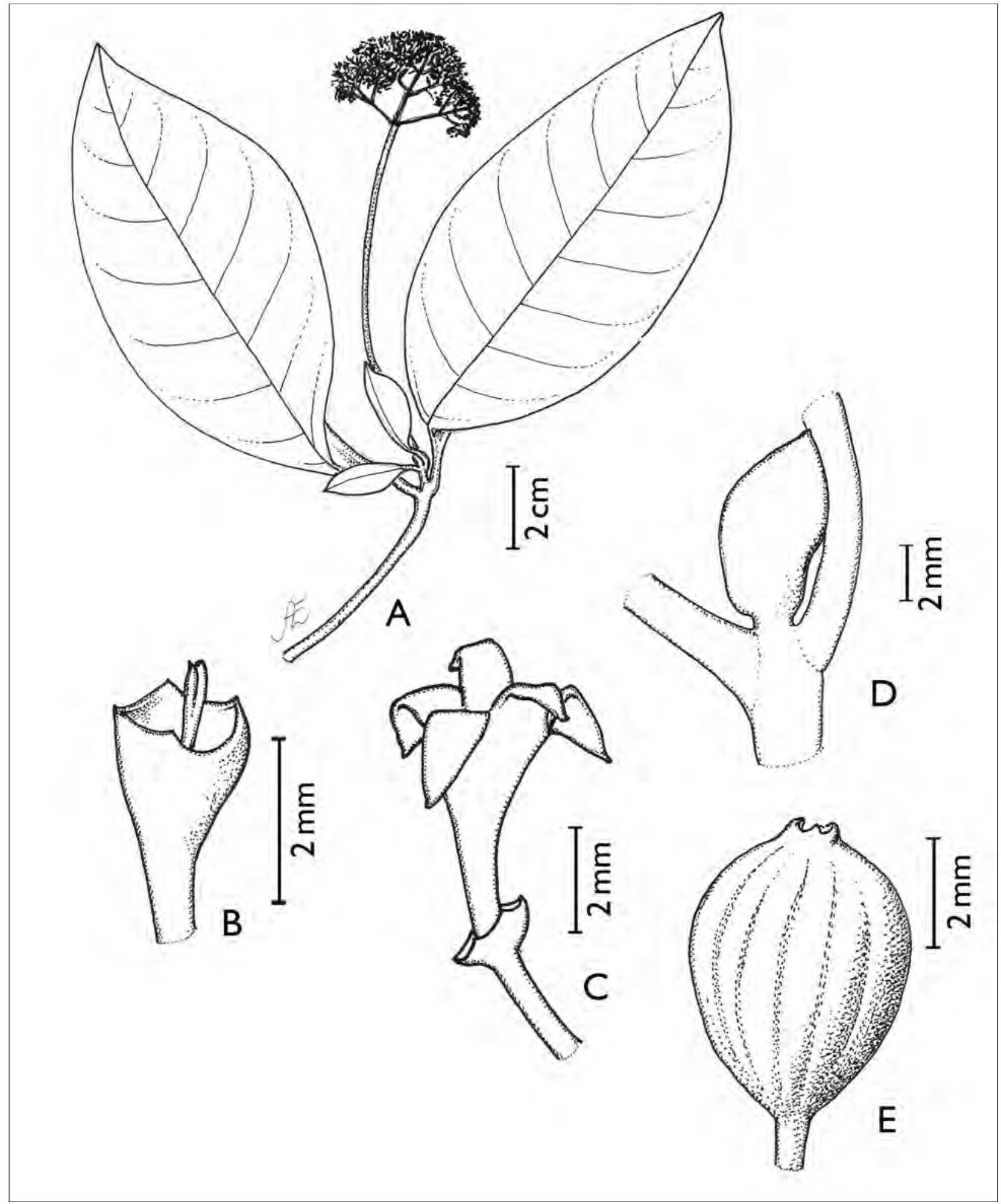

Figura 15. Psychotria mapourioides DC. A. Ramo com inflorescência; B. Cálice; C. Flor; D. Estípula; E. Fruto (M. N. Bastos et al. 597 - MG).

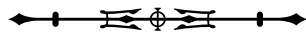


Psychotria mapourioides apresenta uma larga distribuição geográfica na América do Sul tropical. Em relação ao ambiente, a espécie é encontrada em uma grande variedade de habitats, até 2.700 m de altitude (Boom \& Campos, 1991). Na APA de Algodoal/Maiandeua, P. mapourioides é uma espécie frequente no sub-bosque, ocorrendo na formação arbustiva aberta e na mata de Myrtaceae. A espécie foi encontrada florescendo em fevereiro, abril, maio e outubro, e frutificando em abril e maio.

\section{Retiniphyllum schomburgkii (Benth.) Müll. Arg., in Martius, Fl. Bras. 6(5): 12. 1881. Figura 16.}

Arbusto de 1,5 m de altura. Ramos hirsutos; entrenós 0,3-0,4 cm de comprimento. Estípulas interpeciolares truncadas, $2 \mathrm{~mm}$ de comprimento. Folhas opostas, decussadas, pecíolo hirsuto, 0,7-1 cm de comprimento; lâmina oblonga, 8-8,4 × 3,2-3,5 cm; ápice mucronado, base obtusa; margem hirsuta; face adaxial hirsuta sobre a nervura principal, face abaxial hirsuta sobre as nervuras; nervuras curvivênias, dez pares. Inflorescência em espiga. Flores andróginas; com botão floral oblongo, ápice agudo a obtuso, 0,9 cm de comprimento, velutino; cálice tubular pentâmero, 2-2,5 × 2,5 mm, seríceo externamente, glabro internamente; lobos triangulares, $0,5 \mathrm{~mm}$ de comprimento; corola hipocrateriforme, pentâmera, tubo velutino externamente, internamente com um anel de tricomas seríceos, próximos à fauce; lobos 5 , oblongos, 1 $\times 0,2 \mathrm{~cm}$ velutinos; estames 5 , exsertos, alternados com os lobos da corola, inseridos na fauce; filete viloso, $6 \mathrm{~mm}$ de comprimento; antera basifixa, rimosa; ovário globoso, 5-locular, com dois rudimentos seminais por lóculo, axilares; estilete exserto, filiforme, pubescente na região mediana, $1 \mathrm{~cm}$ de comprimento, estigma com cinco lóbulos triangulares. Fruto não observado.

Distribuição geográfica: Colômbia, Venezuela, Guiana, Suriname e Brasil (Cortés \& Steyermark, 2004).

Material examinado: Brasil, Pará: Maracanã, APA de Algodoal/Maiandeua, praia da Princesa, 15/02/2002, L. C. Lobato 2910 (MG).
Retiniphyllum schomburgkii assemelha-se a R. pilosum (Spruce ex Benth.) Müll. Arg. pela pubescência presente nas folhas e estípulas, mas se diferencia pela forma da estípula, oblonga ou oval em $R$. pilosum e truncada em $R$. schomburgkii (Cortés \& Steyermark, 2004). Trata-se de uma nova ocorrência na restinga da APA de Algodoal/Maiandeua. A espécie foi encontrada florescendo em fevereiro.

\section{Tocoyena brasiliensis Mart., Flora 24(2): 82. 1841. Figura 17.}

Arbusto ou árvore de 1,6-5 m de altura. Ramos glabros; entrenós 0,4-9,7 cm de comprimento. Estípulas interpeciolares triangulares, glabras, acuminadas a mucronadas, 0,3-0,4 cm de comprimento. Folhas opostas, decussadas, sésseis a subsésseis; pecíolo glabro, $2 \mathrm{~mm}$ de comprimento; lâmina foliar oblanceolada a espatulada, 4,2-9,8 × 1,5-3,7 cm; ápice agudo, mucronado a obtuso, base aguda a obtusa; margem inteira a híspida; face adaxial glabra, abaxial com acarodomácias nas axilas das nervuras secundárias; nervuras obliquivênias, 6-8 pares. Inflorescência em cimas terminais, sésseis. Flor andrógina, subséssil, 5-8,1 cm de comprimento; botão floral cônico, $1,1 \mathrm{~cm} \times$ 0,7 cm; cálice 5-denteado, persistente, $5 \times 2 \mathrm{~mm}$; corola hipocrateriforme, pentâmera, 5-8,1 cm de comprimento; tubo glabro externa e internamente; lobos oblongos, 1,2 $\times 0,7 \mathrm{~cm}$, pubérulos em apenas uma das bordas; estames 5, inclusos; filete concrescido no tubo da corola; antera dorsifixa, rimosa; ovário bilocular, pluriovulado; estilete exserto, 3,2 cm de comprimento, glabro; estigma bífido. Fruto baga, globosa, 1,5 × 1,3-1,5 cm; sementes 5-7 × 4-5 $\mathrm{mm}$, ovais, achatadas, superfície reticulada.

Distribuição geográfica: $\bigcirc$ tipo foi coletado no Brasil e não são conhecidos espécimes de outros países (Mueller, 1881).

Material examinado: Brasil, Pará: Maracanã, APA de Algodoal/Maiandeua, praia da Princesa, 12/04/1991, M. N. Bastos et al. 748 (MG); praia de Fortalezinha, 15/06/1994, M. N. Bastos et al. 1711 (MG). Material adicional: Brasil, Pará: Santarém, 09/1849, Spruce 358 (Foto do parátipo, NY). 


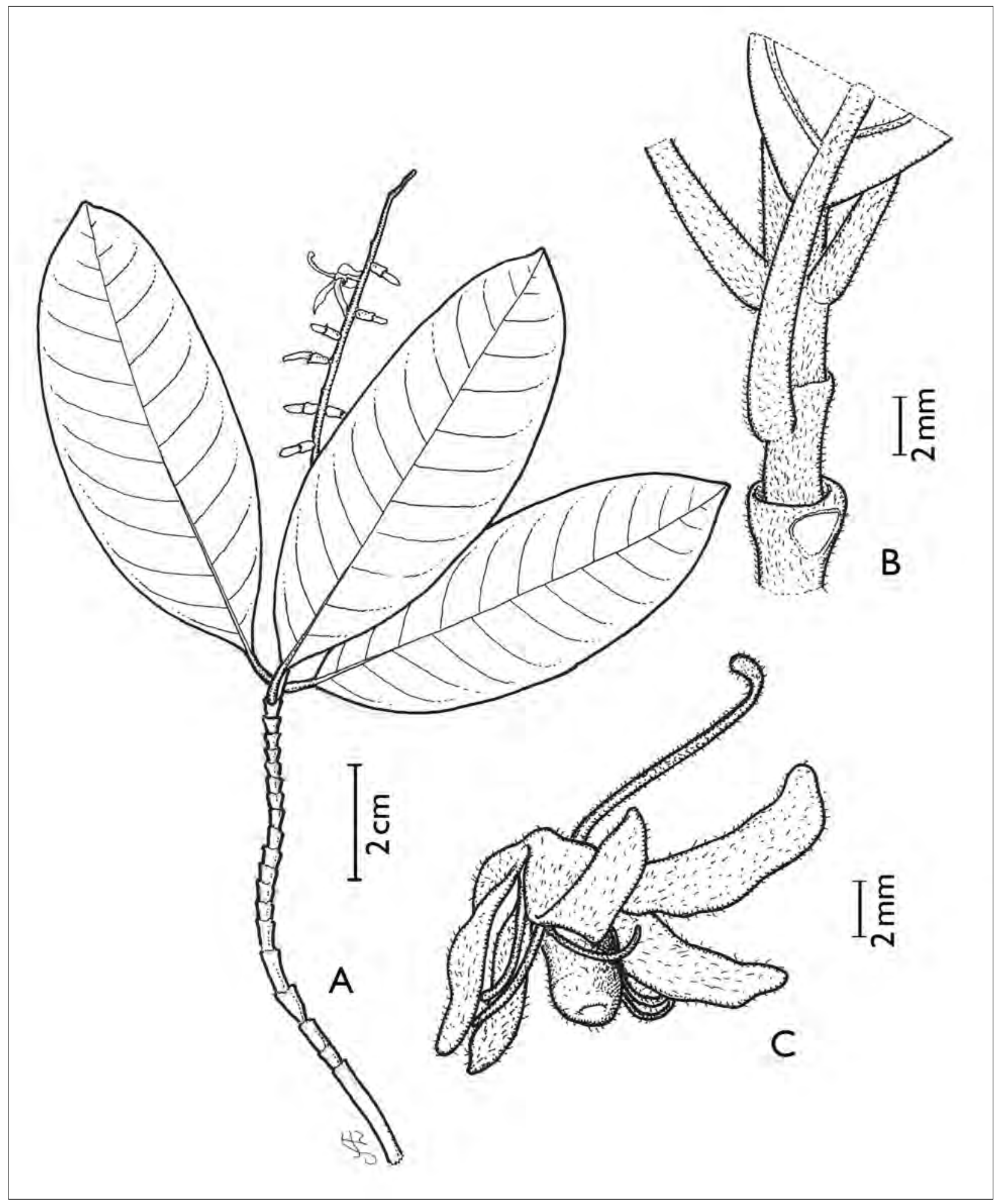

Figura 16. Retiniphyllum schomburgkii (Benth.) Müll. Arg. A. Ramo com inflorescência; B. Estípula; C. Flor (L. C. Lobato 2910 - MG).

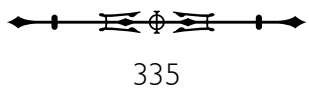




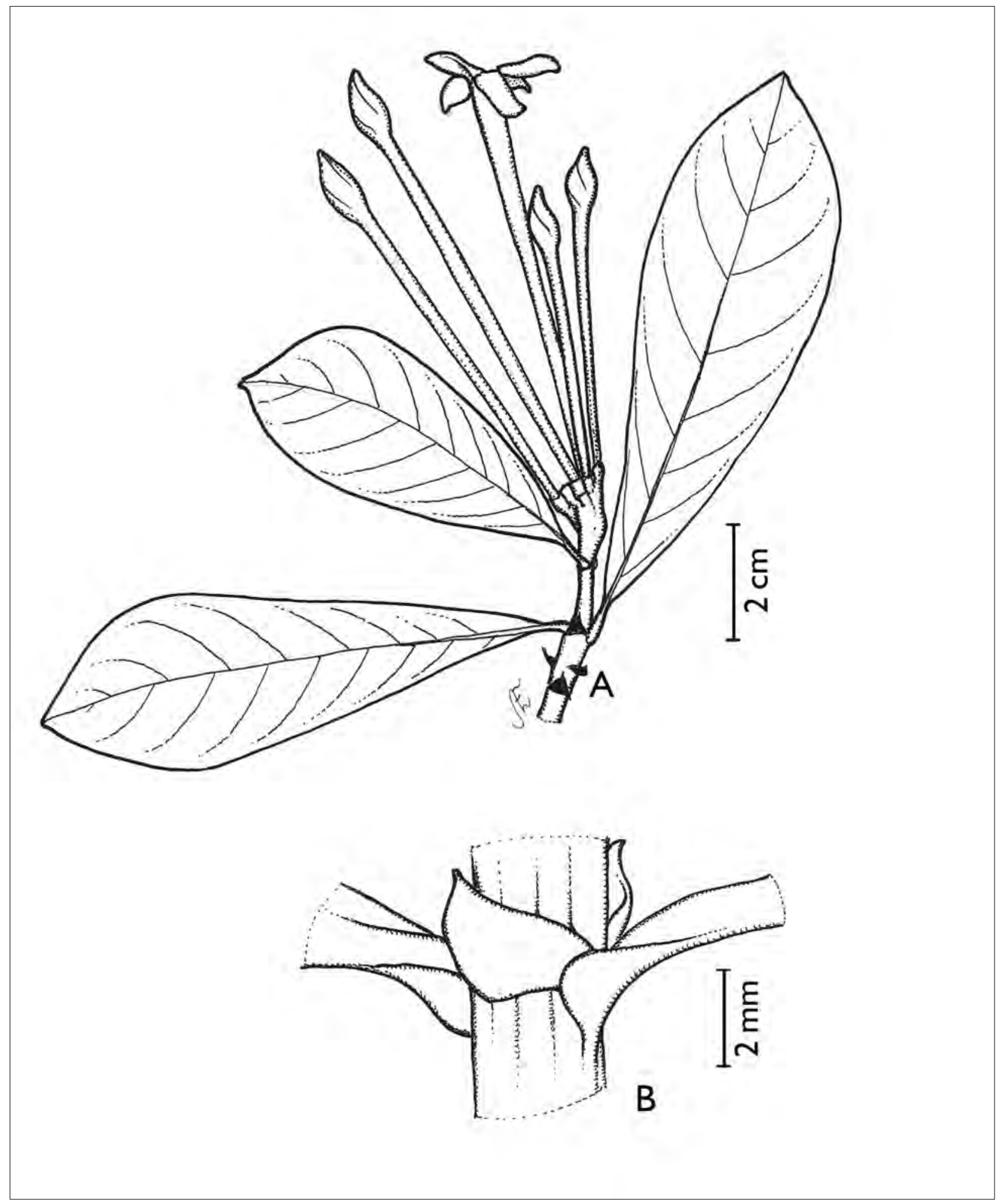

Figura 17. Tocoyena brasiliensis Mart. A. Ramo com inflorescência; B. Estípula (M. N. Bastos et al. 748 - MG).

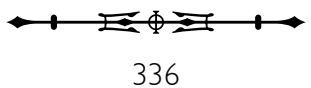


Tocoyena sprucei Standl. é sinônimo de T. brasiliensis, de acordo com Govaerts (2003). Tocoyena brasiliensis assemelha-se a T. sellowiana (Cham. \& Schltdl.) K. Schum. por apresentar o ramo foliar glabro, diferindo pela pilosidade da fauce da corola e pela forma do limbo foliar, sendo vilosa, com limbo obovado, em T. brasiliensis, e glabra, com limbo oblongo-lanceolado, em T. sellowiana. Das folhas de T. brasiliensis, podem-se extrair substâncias, conhecidas como saponinas triterpênicas, utilizadas no combate a um fungo filamentoso fitopatógeno, denominado Cladosporium cladosporioides (Fresen.) de Vries (Hamerski et al., 2005). Ainda segundo estes autores, T. brasiliensis é conhecida popularmente como 'genipapinho'. A espécie foi encontrada florescendo em abril e frutificando em junho.

\section{AGRADECIMENTOS}

À Coordenação de Aperfeiçoamento de Pessoal de Nível Superior (CAPES), pela bolsa de mestrado concedida ao autor; aos pesquisadores especialistas, $\mathrm{Dr}^{\mathrm{a}}$. Charlotte Taylor (Missouri Botanical Garden - MO), Dra . Elsa Cabral (Facultad de Ciencias Exactas y Naturales y Agrimensura - UNNE), Dra. Maria do Socorro Pereira (Universidade Federal de Pernambuco - UFPE), Dr. Piero Delprete (Institut de Recherche pour le Développement - AMAP), Dr. Claes Persson (Universidade de Goteborg - GB), Dr. Alberto Vicentini (Instituto Nacional de Pesquisa da Amazônia - INPA), Dr. Elnatan Souza (Universidade Estadual de Feira de Santana - UEFS) e Dr. Jomar Jardim (UEFS), pela colaboração inestimável, sempre que solicitada, a esta pesquisa; e aos avaliadores pelas valiosas sugestões.

\section{REFERÊNCIAS}

ALBUQUERQUE, J. M. P.,1989. Plantas medicinais de uso popular: 1-96. ABEAS/MEC, Brasília.

AMARAL, D. D., M. T. PROST, M. N. C. BASTOS, S. V. COSTANETO \& J. U. M. SANTOS, 2008. Restingas do litoral amazônico, estados do Pará e Amapá, Brasil. Boletim do Museu Paraense Emílio Goeldi. Ciências Naturais 3(1): 35-67.
ANDERSSON, L., 1992. A provisional checklist of neotropical Rubiaceae. Scripta Botanica Belgica 1: 1-199.

APG II, 2003. An update of the Angiosperm Phylogeny Group classification for the orders and families of flowering plants: APG II. Botanical Journal of the Linnean Society 141: 399-436.

ASSIS, A. M., L. D. THOMAZ \& O. J. PEREIRA, 2004. Florística de um trecho de floresta de restinga no município de Guarapari, Espírito Santo, Brasil. Acta Botanica Brasilica 18(1): 191-201.

ASSUMPÇÃO, J. \& M. T. NASCIMENTO, 2000. Estrutura e composição florística de quatro formações vegetais de restinga no complexo lagunar Grussaí/lquipari, São João da Barra, RJ, Brasil. Acta Botanica Brasilica 14(3): 301-315.

Barroso, G. M., A. L. PeiXOto, C. G. costA, C. L. F. ICHASO, E. F GUIMARÃES \& H. C. LIMA, 1991. Sistemática de Angiospermas do Brasil: 3: 1-326. Imprensa Universitária, Viçosa.

BASTOS, M. N. C., C. S. ROSÁRIO \& L. C. B. LOBATO, 1995. Caracterização fitofisionômica da restinga de Algodoal, Maracanã-PA, Brasil. Boletim do Museu Paraense Emílio Goeldi, série Botânica 11(2): 173-197.

BASTOS, M. N. C., C. SENNA \& S. V. COSTA-NETO, 2002. Comunidades vegetais em paisagem litorânea do Estado do Pará: as restingas de Crispim (Marapanim - PA) e Algodoal (Maracanã - PA). In: L. G. FURTADO \& H. D. A. BARBOSA (Orgs.): Gente e ambiente no mundo da pesca artesanal: (1): 239-258. Museu Paraense Emílio Goeldi, Belém.

BOOM, B. M. \& M. T. V. A. CAMPOS, 1991. A preliminary account of the Rubiaceae of a Central Amazonian Terra Firme Forest. Boletim do Museu Paraense Emílio Goeldi, série Botânica 7(2): 223-247.

BREMER, B., K. ANDREASEN \& D. OLSSON, 1995. Subfamilial and tribal relationships in the Rubiaceae based on $R b c l$ sequence data. Annals of the Missouri Botanical Garden 82: 383-397.

BREMER, B., R. K. JANSEN, B. OXELMAN, M. BACKLUND, H. LANTZ \& K. J. KIM, 1999. More characters or more taxa for a robust phylogeny-case study from the coffee family (Rubiaceae). Systematic Biology 48(3): 413-435.

BRUMMITT, R. K. \& C. E. POWELL, 1992. Authors of plant names. Royal Botanic Gardens, Kew.

BURGER, W. \& C. M. TAYLOR, 1993. Flora Costaricensis. Fieldiana 33: 1-333.

CAMPOS, M. T. V. A., J. M. BRITO \& C. M. TAYLOR, 1999. Rubiaceae. In: J. E. L. RIBEIRO, M. J. G. HOPKINS, A. VICENTINI, C. A. SOTHERS, M. A. S. COSTA, J. M. BRITO, M. A. D. SOUZA, L. H. P. MARTINS, L. G. LOHMANN, P. A. C. L. ASSUNÇÃO, E. C. PEREIRA, C. F. SILVA, M. R. MESQUITA \& L. C. PROCÓPIO (Eds.): Flora da Reserva Ducke. Guia de identificação das plantas vasculares de uma floresta de terra-firme na Amazônia Central: 1-816. INPA, Manaus. 
CAVALCANTE, P. B., 1996. Frutas comestíveis da Amazônia: 1-279. Museu Paraense Emílio Goeldi (Coleção Adolpho Ducke), Belém.

CHIQUiERI, A., F. R. DI MAIO \& A. L. PEIXOTO, 2004. A distribuição geográfica da família Rubiaceae Juss. na Flora Brasiliensis de Martius. Rodriguésia 55(84): 47-57.

CORTÉS, R. \& J. A. STEYERMARK, 2004. Retiniphyllum. In: J. A. STEYERMARK, P. E. BERRY, K. YATSKIEVYCH \& B. K. HOLST (Eds.): Flora of the Venezuelan Guayana: 8: 497-848. Missouri Botanical Garden Press, St. Louis, USA.

CRONQUIST, A., 1981. An Integrated System of Classification of Flowering Plants: 1-1262. Columbia University Press, New York.

DELPRETE, P. G., 1999. Rondeletieae (Rubiaceae) - Part I (Rustia, Tresanthera, Condaminea, Picardaea, Pogonopus, Chimarrhis, Dioicodendron, Molopanthera, Dolichodelphys, and Parachimarrhis). Flora Neotropica 77: 1-225.

DELPRETE, P. G. \& C. PERSSON, 2004. Alibertia. In: J. S. STEYERMARK, P. E. BERRY \& B. K. HOLST (Eds.): Flora of the Venezuelan Guayana: 8: 497-848. Missouri Botanical Garden Press, St. Louis, USA.

DWYER, J. D., 1980. Rubiaceae. In: R. E. WOODSON \& R. W. SCHERY (Eds.): Flora of Panamá part IX. Annals of the Missouri Botanical Garden 67: 1-522.

ENGLER, A., 1954. Syllabus der Pflanzenfamilien: 1(12): 367. Borntraeger, Berlin.

FIDALGO, O. \& V. L. R. BONONI, 1989. Técnicas de coleta, preservação de material botânico: 1-62. Instituto de Botânica (Série Documentos), São Paulo.

FORERO, L. E., 1980. Etnobotánica de las comunidades indígenas Cuna y Waunana, Chocó (Colombia). Cespedesia 9(33-34): 115-301.

FOSBERG, F. R., M. H. SACHET \& R. L. OLIVER, 1993. Rubiaceae. Flora of Micronesia 5. Smithsonian Contributions to Botany 81: 44-135.

FRANCISCO, N. M. A. C., R. C. ARGÔLO FILHO, B. M. MACIEL, R. P. REZENDE \& A. C. SCHMITT, 2004. Avaliação da atividade antibacteriana in vitro da planta Guettarda angelica sobre salmonelas isoladas das fezes de Teiús. Anais do $10^{\circ}$ Seminário de Iniciação Científica da UESC 133-134.

GEMTCHÚJNICOV, I. D., 1976. Manual de taxonomia vegetal: plantas de interesse econômico: 1-368. Agronômica Ceres, São Paulo.

GOVAERTS, R., 1996. Spermacoce (Rubiaceae). In: World Checklist of Seed Plants. Continental Publishing, Antwerp 2(1): 14-19.
GOVAERTS, R., 2003. World Checklist of Selected Plant Families Database in ACCESS: 1-216203. The Board of Trustees of the Royal Botanic Gardens, Kew.

HAMERSKI, L., C. A. CARBONEZI, A. J. CAVALHEIRO, V. S. BOLZANI \& M. C. M. YOUNG, 2005. Saponinas Triterpênicas de Tocoyena brasiliensis Mart. (Rubiaceae). Química Nova 28(4): 601-604.

LAWRENCE, G. H. M., 1973. Taxonomia das plantas vasculares: 2: 1-855. Calouste-Gulbenkien, Lisboa.

LEITE, A. V. L. \& L. H. C. ANDRADE, 2004. Riqueza de espécies e composição florística em um ambiente de duna após 50 anos de pressão antrópica: um estudo na Praia de Boa Viagem, Recife, PE - Brasil. Biotemas 17(1): 29-46.

MENDOZA, H., B. Y. RAMÍREZ \& L. C. JIMÉNEZ, 2004. Rubiaceae de Colombia: 1-351. Instituto de Investigación de Recursos Biológicos Alexander von Humboldt, Bogotá.

MORI, S. A., G. CREMERS, C. A. GRACIE, J. J. GRANVILLE, S. V. HEALD, M. HOFF \& J. D. MITCHELL, 2002. Guide to the vascular plants of Central French Guiana. Part 2. Dicotyledons. Memoirs of the New York Botanical Garden 76: 1-776.

MUELLER, A. J., 1881. Rubiaceae. In: C. F. P. MARTIUS (Ed.): Flora Brasiliensis 6(5): 1-470.

PEREIRA, M. S. \& M. R. V. BARBOSA, 2004. A família Rubiaceae na Reserva Biológica Guaribas, Paraíba, Brasil. Subfamílias Antirheoideae, Cinchonoideae e Ixoroideae. Acta Botanica Brasilica 18(2): 305-318.

PEREIRA, M. S. \& M. R. V. BARBOSA, 2006. A família Rubiaceae na Reserva Biológica Guaribas, Paraíba, Brasil. Subfamília Rubioideae. Acta Botanica Brasilica 20(2): 455-470.

PERSSON, C., P. DELPRETE \&J. A. STEYERMARK, 2004. Cordiera. In: J. A. STEYERMARK, P. E. BERRY, K. YATSKIEVYCH \& B. K. HOLST (Eds.): Flora of the Venezuelan Guayana: 8: 497-848. Missouri Botanical Garden Press, St. Louis, USA.

PINTO, G. C. P., H. P. BATISTA \& J. C. A. FERREIRA, 1984 A restinga do litoral nordeste do Estado da Bahia. In: L. D. LACERDA, D. S. D. ARAÚJO, R. CERQUEIRA \& B. TURQ (Eds.): Restingas: origem, estrutura e processos: 195-216. CEUFF, Niterói.

RIZZINI, C. T., 1977. Sistematização terminológica da folha. Rodriguésia 29(42): 103-125.

RIZZINI, C. T. \& C. M. RIZZINI, 1983. Dicionário botânico clássico latino-português abonado: 1-283. Jardim Botânico do Rio de Janeiro, Rio de Janeiro.

ROBBRECHT, E., 1988. Tropical woody Rubiaceae. Opera Botanica Belgica 1: 1-127. 
ROBBRECHT, E., 1993. On the delimitation of the Rubiaceae. A review. Opera Botanica Belgica 6: 19-30.

ROBBRECHT, E. \& J. F. MANEN, 2006. The major evolutionary lineages of the coffee family (Rubiaceae, angiosperms). Combined analysis (nDNA and cpDNA) to infer the position of Coptosapelta and Luculia, and supertree construction based on rbcL, rps16, trnL-trnF and $a t p B-r b c L$ data. A new classification in two subfamilies, Cinchonoideae and Rubioideae. Systematic and Geography of Plants 76: 85-146.

RUSBY, H. H., 1920. Descriptions of three hundred new species of South American plants. 1-170. Henry Hurd, New York.

SCHULTZ, A. R., 1963. Introdução ao estudo da botânica sistemática: 1-427. Ed. Globo, Porto Alegre.

SCHUMANN, K., 1888. Rubiaceae. In: C. F. P. MARTIUS (Ed.): Flora Brasiliensis 6(6): 1-123.

SCHUMANN, K., 1889. Rubiaceae. In: C. F. P. MARTIUS (Ed.): Flora Brasiliensis 6(6): 124-466.

SCHUMANN, K., 1891. Rubiaceae. In: A. ENGLER \& K. PRANTL (Eds.): Die Natürlichen Pflanzenfamilien 4(4): 1-156.

SOUZA, V. C. \& H. LORENZI, 2005. Botânica sistemática: guia ilustrado para identificação das famílias de angiospermas da flora brasileira, baseado em APG II. Instituto Plantarum, Nova Odessa.

STANDLEY, P. C., 1931. Rubiaceae of Bolivia. Publications of the Field Museum of Natural History, botanical series 7(3): 253-340.

STEYERMARK, J. A., 1965. Rubiaceae. In: J. A. STEYERMARK \& B. MAGUIRE (Eds.): The Botany of the Guayana Highland, Part. VI. Memoirs of the New York Botanical Garden 12: 198-207.

STEYERMARK, J. A., 1972. Rubiaceae. In: J. A. STEYERMARK \& B. MAGUIRE (Eds.): The Botany of the Guayana Highland, Part. IX. Memoirs of the New York Botanical Garden 23: 227-832.
STEYERMARK, J. A., 1988. Notes on Oldenlandia filicaulis and Oldenlandia tenuis (Rubiaceae). Annals of the Missouri Botanical Garden 75(2): 736-738.

TAYLOR, C. M., J. A. STEYERMARK, P. G. DELPRETE, A. VICENTINI, R. CORTÉS, D. ZAPPI, C. PERSSON, C. B. COSTA \& E. A. ANUNCIAÇÃO, 2004. Rubiaceae. In: J. A. STEYERMARK, J. S. STEYERMARK, P. E. BERRY \& B. K. HOLST (Eds.): Flora of the Venezuelan Guayana: 8: 497-848. Missouri Botanical Garden Press, St. Louis, USA.

TROPICOS, 2009. Tropicos.org. Missouri Botanical Garden. Disponível em: <http://www.tropicos.org > . Acesso em: 10 dezembro 2007.

VERDCOURT, B., 1958. Remarks on the classifications of the Rubiaceae. Bulletin du Jardin Botanique de État à Bruxelles 28: 209-290.

VERDCOURT, B., 1975. Studies in the Rubiaceae - Rubioideae for the "Flora of Tropical East Africa": I. Kew Bulletin 30: 247-326.

VERDCOURT, B., 1976. Spermacoce. In: R. M. POLHILL (Ed.): Flora of Tropical East Africa. Rubiaceae part 1: 339-374. Crown Agents for Oversea Governments and Administrations, London.

VIANA, B. F., F. O. SILVA \& A. M. P. KLEINERT, 2006. A flora apícola de uma área restrita de dunas litorâneas, Abaeté, Salvador, Bahia. Revista Brasileira de Botânica 29(1): 13-25.

VICENTINI, A. \& J. A. STEYERMARK, 2004. Pagamea. In: J. A. STEYERMARK, P. E. BERRY, K. YATSKIEVYCH \& B. K. HOLST (Eds.): Flora of the Venezuelan Guayana: 8: 666-678. Missouri Botanical Garden Press, St. Louis, USA.

Recebido: 24/04/2008 Aprovado: 18/09/2009

Responsabilidade editorial: Anna Luiza Ilkiu Borges

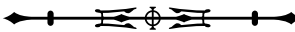


